\title{
An in situ shelly fauna from the lower Paleozoic Zapla diamictite of northwestern Argentina: Implications for the age of glacial events across Gondwana
}

\author{
Juan L. Benedetto ${ }^{\text {a, }}$, Karen Halpern ${ }^{a}$, G. Susana de la Puente ${ }^{b}$, César R. Monaldi ${ }^{c}$ \\ ${ }^{a}$ CONICET - Centro de Investigaciones en Ciencias de la Tierra (CICTERRA) y Universidad Nacional de Córdoba, Av. Vélez Sarsfield 1611, Ciudad \\ Universitaria, X5016GCA Córdoba, Argentina \\ ${ }^{\mathrm{b}}$ CONICET - Departamento de Geología y Petróleo, Facultad de Ingeniería, Universidad Nacional del Comahue, Buenos Aires 1400, Q8300IBX Neuquén, \\ Argentina \\ ${ }^{\mathrm{c}}$ CONICET - Universidad Nacional de Salta, Argentina
}

\section{A R T I C L E I N F O}

\section{Article history:}

Received 24 April 2015

Received in revised form

5 October 2015

Accepted 8 October 2015

Available online 22 October 2015

\section{Keywords}

Brachiopods

Trilobites

Hirnantian/Silurian biostratigraphy

Glacial diamictites

Subandean ranges

South American basins

Gondwana

\begin{abstract}
A B S T R A C T
A shelly fauna from the upper part of the Zapla glacial diamictite includes the lingulate brachiopod Orbiculoidea radiata Troedsson, the rhynchonelliforms Dalmanella cf. testudinaria (Dalman) and Paromalomena sp., the bivalve Modiolopsis? sp., and the trilobite Dalmanitina subandina Monaldi and Boso. Both taphonomic and paleoecologic data indicate a lack of transport reflecting the original community. The assemblage is closely comparable to the widespread latest Ordovician Hirnantia-Dalmanitina fauna. The Hirnantian age of the Zapla diamictite is further corroborated by the record of the northern Gondwana chitinozoans Spinachitina cf. oulebsiri Paris and Desmochitina minor typica Eisenack. The graptolites and chitinozoans from the overlying Lipeón Formation indicate that the postglacial transgression took place in the earliest Llandovery (Parakidograptus acuminatus Biozone). According to the tectonosedimentary evidence, the Early Silurian age of the Cancañiri and San Gabán diamictites of north -central Bolivia and south Peru based on their palynological record is more likely the age of posglacial gravity flows and not that of the glaciation. We support the hypothesis that the weakly lithified glacigenic deposits of Hirnantian age were reworked and redistributed by high-energy marine processes during the postglacial transgression and then transported to the adjacent deep-marine trough. Iron-rich horizons have been recognized in many basins of southern South America reflecting eustatic and paleoclimatic fluctuations. Most of them formed during the early stages of the postglacial transgression at the Ordovician/Silurian transition and are associated with low sedimentation rates and condensed intervals. The mild maritime postglacial climate, the increasing atmospheric $\mathrm{CO}_{2}$, and possibly the presence of incipient vegetated areas led to extensive weathering of glacigenic sediments supplying iron into the marine system to form ferruginous deposits. The sea level fall related to the peak of glaciation is recorded by both paleovalley incision and a sharp subaerial to subglacial unconformity. The transgressive systems tract starts with fluvio-estuarine deposits within incised valleys followed by widespread deposition of subtidal to open marine organic-rich shales onlapping regionally the basement rocks. The recognition of key stratigraphic markers (e.g. sequence boundary, flooding surface, ferruginous beds), alongside reliable micro and macropaleontological evidence allow a more accurate correlation between the Central Andean Basin of Peru, Bolivia and NW Argentina, the W Puna region, the Paraguayan and Brazilian sectors of the Paraná Basin, the Precordillera Basin of W Argentina, and the Cape Basin of South Africa.

๑) 2015 Elsevier Ltd. All rights reserved.
\end{abstract}

\footnotetext{
* Corresponding author.

E-mail addresses: jbenedetto@efn.uncor.edu (J.L. Benedetto), karenhalpern@ gmail.com (K. Halpern), sudelapuente@gmail.com (G.S. de la Puente), crmonaldi@ gmail.com (C.R. Monaldi).
}

\section{Introduction}

In the Central Andes, a lower Paleozoic diamictite extends over more than $300,000 \mathrm{~km}^{2}$ through southern Peru, Bolivia and northwestern Argentina. This stratigraphic unit has been referred 
to in Peru as the San Gabán Formation, in Bolivia as Cancañiri Formation, and in Argentina as Zapla Formation (the names Mecoyita and Caspalá have also been used for other localities). The thickness of the diamictite unit varies from ca. $1500 \mathrm{~m}$ in the depocenter located west of Potosí in the Cordillera Oriental (Eastern Cordillera) of Bolivia, to a few tens of meters towards the basin margins (Suárez Soruco, 1995; Díaz-Martínez and Grahn, 2007). Throughout the Central Andean Basin the diamictite rests upon a regional erosional surface truncating different Lower to Upper Ordovician (Sandbian/Katian) siliciclastic marine units. Its glacial origin was first postulated by Schlagintweit (1943) who introduced the name 'Horizonte Glacial de Zapla' (Zapla Glacial Horizon) for the diamictite that immediately underlies conspicuous iron-rich levels in the Sierra de Zapla (Zapla Range) of northwestern Argentina. Since then, the Zapla Formation and correlative units of Bolivia and Peru have been considered by most authors as glacimarine in origin (Berry and Boucot, 1972; Crowell et al., 1981; Buggisch and Astini, 1993; Astini, 2003), though evidence of synsedimentary deformation structures led to interpret the diamictite as glacigenic sediments redeposited in deeper waters (Rodrigo et al., 1977; Sempere, 1995; Díaz-Martínez and Grahn, 2007). The diamictite succession of southern Bolivia (e.g. Tarija region) has been interpreted as true tillites deposited during successive advances of temperate grounded glaciers in a glacioterrestrial environment (Schönian et al., 1999; Schönian and Egenhoff, 2007). By contrary, Boso (1996) rejected the glacial origin of the Zapla diamictite arguing that sedimentary structures point to large-scale sediment gravity flows in a tectonically unstable basin. This hypothesis, however, does not account for the abundance of faceted and striated clasts within the diamictite. Nevertheless, it should be noted that the occurrence of large-scale, tectonically induced events (Díaz Martínez et al., 1996, 2001; Egenhoff and Lucassen, 2003 ) is not incompatible with glaciated areas in the region.

The age of the diamictite remains controversial due to the reworked nature of most of the fossils and, additionally, by the fact that some fossiliferous beds attributed to the upper part of the Cancañiri Formation (e.g. those yielding the Silurian shelly faunas described by Antelo, 1973) are currently ascribed to the base of the overlying non-glacial Kirusillas Formation (Benedetto and SuárezSoruco, 1998). Further data from chitinozoans recovered from the Zapla Formation (Grahn and Gutiérrez, 2001) and the Cancañiri Formation (Díaz Martínez and Grahn, 2007; Díaz Martínez et al., 2011) allow reinterpreting the 'Cancañiri glacial event' as essentially Early Silurian. This age has been uncritically accepted in some global-scale Early Paleozoic paleoclimatic discussions (i.e. Brand et al., 2006; Eyles, 2008; Cherns and Wheeley, 2009; Lehnert et al., 2010; Loi et al., 2010). However, an increasing amount of micro and macropaleontological evidence, including the fauna described in the present work, tends to constrain the main glacial advance in the Central Andean Basin essentially to the Hirnantian in accordance with the timing of the glaciation peak in northern Gondwana and other regions of the world.

The aim of this paper is to briefly describe and illustrate the shelly fauna recovered from the glacial diamictite of the Zapla Formation exposed in the Sierra de Santa Bárbara of northwestern Argentina. The interest of this assemblage lies in its undoubtedly autochthonous nature, then providing critical information on the age of the end of the main phase of the glacial event as well as the beginning of the subsequent marine transgression triggered by the ice cap melting. We also propose some explanations to account for the inconsistency in the age of the diamictites of Argentina, Bolivia and Peru. Finally, we attempt a regional correlation of the Upper Ordovician/Lower Silurian successions of southern South America to enlighten the complex dynamic of the end-Ordovician glacial event in the high-latitude western Gondwana.

\section{Stratigraphy, taphonomy and paleocology}

The fauna was collected from the Zapla Formation exposed along the Arroyo Pedregoso creek (Pedregoso River) in the southern part of the Sierra de Santa Bárbara (Fig. 1). This range, together with the adjacent Sierra de Zapla and other mountain systems, constitutes the Subandean Ranges morphotectonic unit (Rolleri, 1976; Kley and Monaldi, 1999, 2002). In the studied area, the Zapla Formation overlies unconformably the Centinela Formation, of probable Sandbian age, which consists of Skolithos-rich quartzsandstones interbedded near the base with greenish siltstones bearing fragments of linguliform brachiopods. The thickness of the Zapla Formation in the Arroyo Pedregoso section is of $78 \mathrm{~m}$ (Fig. 2). The lower $15 \mathrm{~m}$ consist of dark gray massive diamictites intercalated with a ca. $1 \mathrm{~m}$ thick bed of coarse-grained quartz-sandstones. This interval is followed by a lenticular sandstone bed reaching a maximum thickness of $5 \mathrm{~m}$, consisting of fine-to very coarsegrained sandstone showing diffuse low-angle cross stratification. Higher in the section the massive diamictites are interbedded with packages up to $25 \mathrm{~m}$ thick of lenticular quartz-sandstones displaying hummocky cross stratification. Throughout the unit diamictites contain small quartz grains and boulders up to $20 \mathrm{~cm}$ in diameter of quartzite, shale, granitoids, chert, and diamictite reworked from the same unit, and scarce pyrite nodules. The sandstone beds are contorted and often broken appearing as isolated blocks of quartzite, denoting synsedimentary soft deformation linked probably to glacial processes. At the top of the section the diamictites are intercalated with thin beds of dark gray mudstones yielding the fauna described herein (Fig. 2). These levels bear scattered quartz clasts ( $<5 \mathrm{~mm}$ in diameter) that may represent icederived dropstones.

The Zapla Formation is conformably overlain by the Lipeón Formation (=Cachipunco Formation), which starts with ca. $10 \mathrm{~m}$ thick fine-grained micaceous gray sandstones followed by a conspicuous chamoisitic oolitic ironstone bed reaching $1.50 \mathrm{~m}$ in thickness. This horizon is overlain by yellowish fine-grained micaceous sandstones with abundant Zoophycos followed by a second ferruginous sandstone reaching $3.70 \mathrm{~m}$ in thickness. The exposed stratigraphic section culminates with dark gray micaceous shales and sandstones truncated by an inverse fault against Cenozoic rocks.

As stated above, the studied fauna comes from a dark gray mudstone bed near the top of the Zapla Formation. The only trilobite recovered is Dalmanitina subandina (Monaldi and Boso, 1987). This species is represented by isolated pigydia, cranidia and free checks corresponding probably to molt remains. Some bivalve specimens (Modiolopsis? sp.) are preserved with their valves open but united along the hinge (Fig. 4). Because this genus is edentulous, post mortem resistance to disarticulation after the ligament decay should have been very low, and then this is important evidence against hydrodynamic transport or long residence time on the substrate. Although valves transported by nonturbulent sediment gravity flows can occasionally remain conjoined, there is no sedimentological evidence of such processes in the sampled interval.

Brachiopods are the more abundant component of the Zapla community, the small organophosphatic discinoidean Orbiculoidea radiata Troedsson being largely dominant (Fig. 3). This species is represented by both dorsal and ventral valves, but the former are more numerous and better preserved than the thinner and flattened ventrals. The presence of juvenile and adult shells in the same bedding plane reveals absence of sorting. Moreover, although valves of 0 . radiata and associated rhynchonelliform brachiopods are disarticulated do not show signs of mechanical damage and their external ornament is finely preserved, indicating absence of 


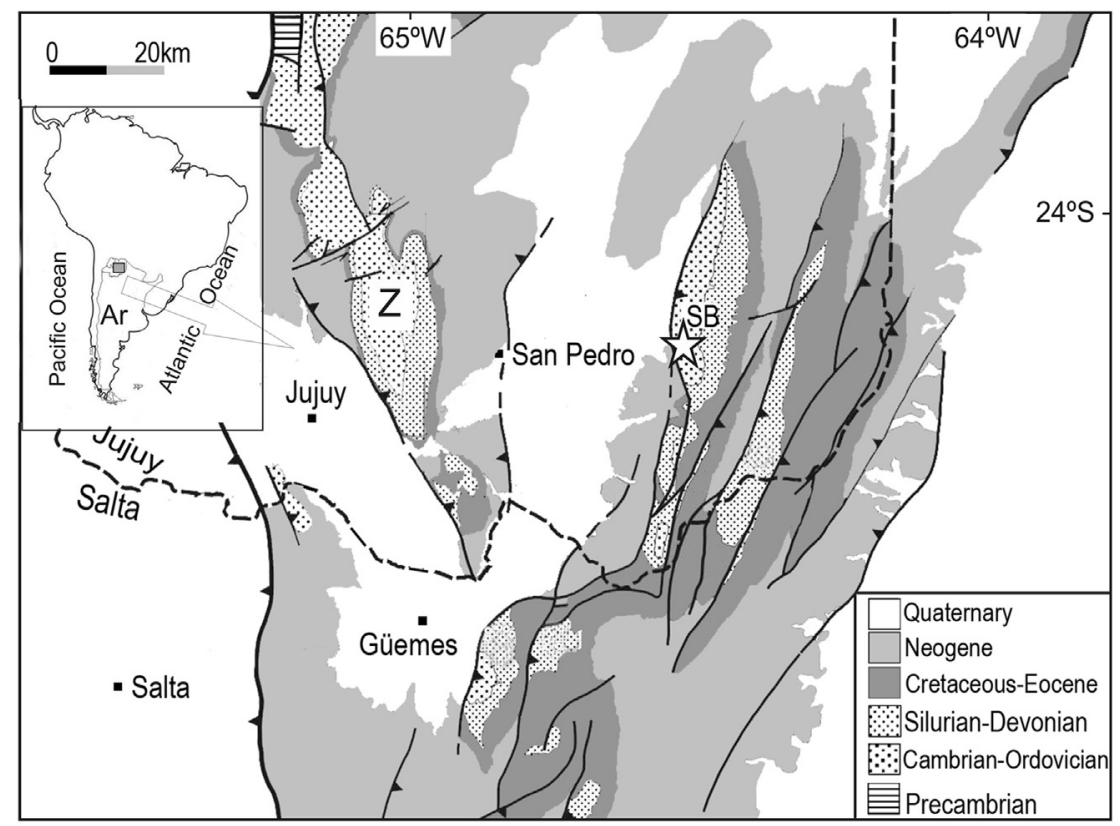

Fig. 1. Geological map of the Subandean Ranges in NW Argentina showing location of the fossiliferous site (star). SB: Sierra de Santa Bárbara; Z: Zapla Range anticline.

winnowing by currents or waves.

O. radiata is an epifaunal linguliformean brachiopod. Like other discinaceans it lay attached to the substrate by its short pedicle. The widespread genus Orbiculoidea inhabited in a wide range of depths, but more frequently occurs in subtidal dark gray mudstones and shales reflecting poorly oxygenated bottoms. Burrowing linguliformeans, which are better adapted to cope fluctuations in water energy, salinity and temperature, are absent in the Zapla community. Dalmanella cf. testudinaria Dalman is the most abundant rhynchonelliform brachiopod. Dalmanella is a typical orthide with biconvex shell and permanent open delthyrium, living umbo-down attached to the bottom by mean of a strong pedicle. It is considered a eurytopic form capable to inhabit shallow to deep waters in carbonate or siliciclastic environments (Brenchley and Cocks, 1982). Paromalomena, as most strophomenoids, lived free on soft bottoms with the slightly convex ventral valve downward partially sunk into the sediment (Bassett, 1984). Modiolopsis was a suspension feeder semi-infaunal bivalve fixed to the substrate by a byssus.

The low diversity of the Zapla assemblage (five taxa) was probably caused by slightly dysoxic bottom conditions, episodic input of coarse sediments, and/or salinity fluctuations. It closely resembles the Hirnantia-Modiolopsis Community recorded in the Don Braulio Formation of the Argentine Precordillera, which occurs in gray bioturbated calcareous mudstones just above the glacigenic diamictite (Sánchez et al., 1991). The Zapla and Don Braulio communities have in common a dalmanitid trilobite (see Dalmanitina) Mucronaspis remarks bellow), Orbiculoidea (the specimens from the Don Braulio Formation are illustrated for the first time in the present paper), Dalmanella, Paromalomena, and probably Modiolopsis. The Precordilleran assemblage, however, is more diverse, and Hirnantia sagittifera and Dalmanella testudinaria are the commonest brachiopod. Moreover, in the Hirnantia-Modiolopsis community, bryozoans are relatively frequent including a stick cylindrical form (Helopora fragilis) and small branched phylloporinid colonies (Halpern and Carrera, 2014). These bryozoans, together with the brachiopods $H$. sagittifera, Cliftonia oxoplecioides, and Dalmanella testudinaria, the gastropod Holopea sp., and ambonychiid bivalves, are particularly abundant in a thin but widespread transgressive quartz-conglomerate/sandstone bed at the top of the diamictite
(Carrera and Halpern, 2011; Benedetto et al., 2011). The comparatively higher richness of the assemblage from the Precordillera terrane may be due to its location at a lower latitude than the autochthonous Gondwanan basins (Fig. 8). Available samples from the Zapla Formation, however, are by far more reduced that the much larger collections from the Don Braulio Formation, and consequently that values of diversity and relative abundance of taxa may be biased by the nature of sampling.

The Zapla community shows similarities to the fauna recovered from the Kyrkås Quartzite of Sweden, which besides typical elements of the Hirnantia Fauna contains Orbiculoidea cf. radiata and diverse articulated bivalves including Modiolopsis? sp. (Dahlqvist et al., 2010). Also comparable are the Hirnantia Fauna from the Holy Cross Mountain of Poland described by Temple (1965), and the Dalmanella Association of the Oslo-Asker District of Norway (Brenchley and Cocks, 1982). The latter assemblage is characterized by the dominance of $D$. testudinaria and the presence of the bryozoan Hallopora? sp.

\section{Composition of the fauna (by J.L. Benedetto and K. Halpern)}

Illustrated specimens are deposited in the paleontological collection housed in the Centro de Investigaciones en Ciencias de la Tierra (CICTERRA), Consejo Nacional de investigaciones Científicas y Técnicas and Universidad Nacional de Córdoba, Argentina (acronym CEGH-UNC). Prefix CNS-I corresponds to the collection of Department of Ciencias Naturales of the Universidad Nacional de Salta). Prefix LO corresponds to the Departament of Geology, Lund (Sweden), and BB to The Natural History Museum, London.

\subsection{Brachiopods}

Order LINGULIDA Waagen, 1885

Superfamily DISCINOIDEA Gray, 1840.

Family DISCINIDAE Gray, 1840.

Genus Orbiculoidea d'Orbigny, 1847

Type Species: Orbicula forbesii Davidson, 1848. Silurian (Wenlock), England. 


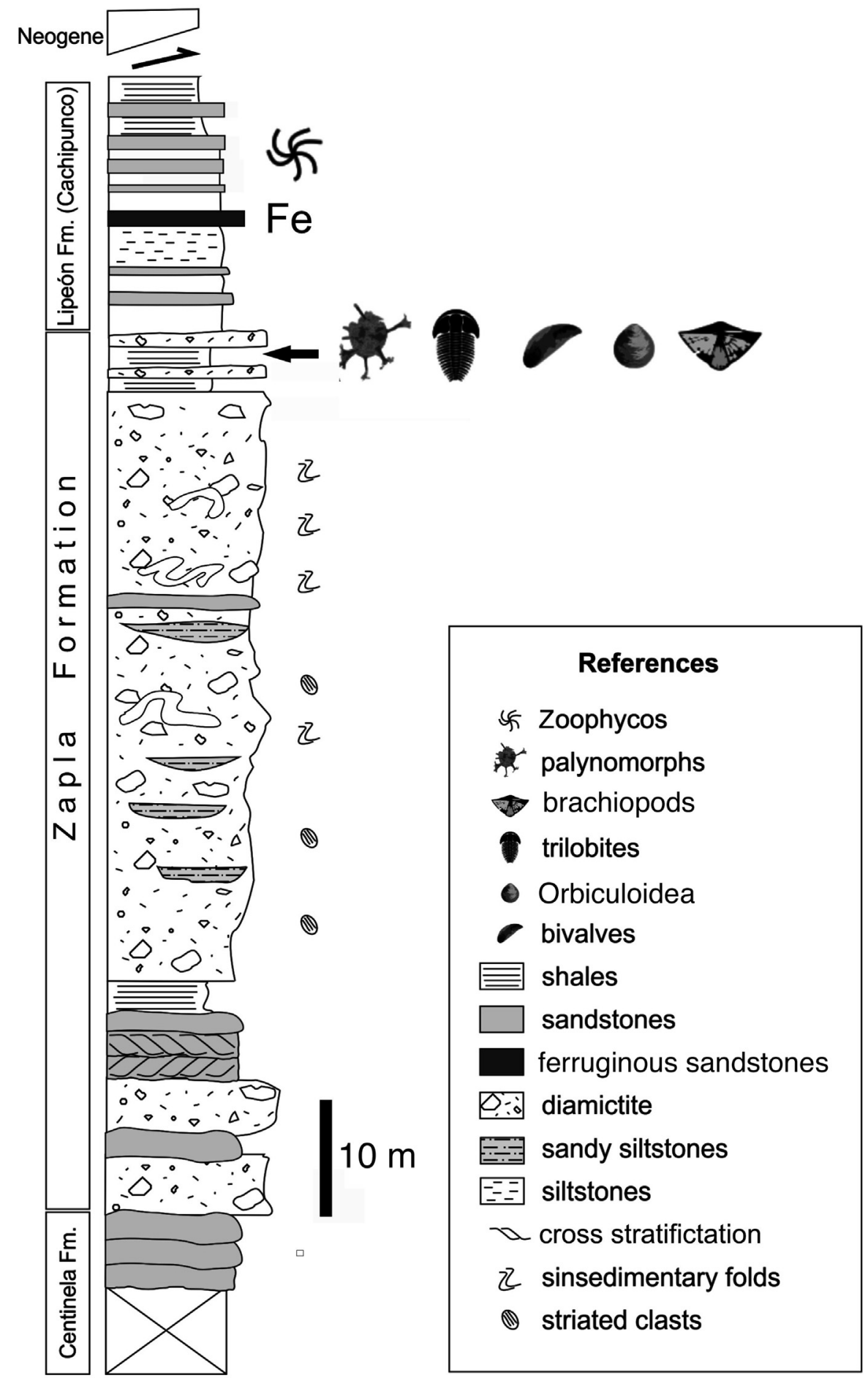

Fig. 2. Stratigraphic column of the Arroyo Pedregoso section showing fossiliferous level at the top of the Zapla Formation.

Orbiculoidea radiata Troedsson, 1918.

Fig. 3.1-3.5, 3.9-3.11.

Material: Twelve valves CEGH-UNC 26001-26012 from the Zapla Formation, Sierra de Santa Bárbara (Arroyo Pedregoso), Jujuy Province, Argentina; six valves CEGH-UNC 26044-26049 from the Don Braulio Formation, Cerro La Chilca, San Juan Province, Argentina.

Remarks: The Zapla specimens display the chief diagnostic features of the type material of 0 . radiata Troedsson from Röstånga,
Sweden (re-illustrated here in Fig. 3.6-3.8), among them their small shell size (maximum width ca. $4.5 \mathrm{~mm}$ ), subcircular outline, conspicuous concentric growth fila crossed by weak radial plications, slightly eccentric ventral umbo located at about one-third of the length from posterior margin, and dorsal valve more convex than ventral with the umbo located near to the posterior margin. The same species has also been reported from the Dalmanitina Beds of the Holy Cross Mountains of Poland and the Hirnant Beds of north Wales (Temple, 1965) (some of these specimens re-illustrated 

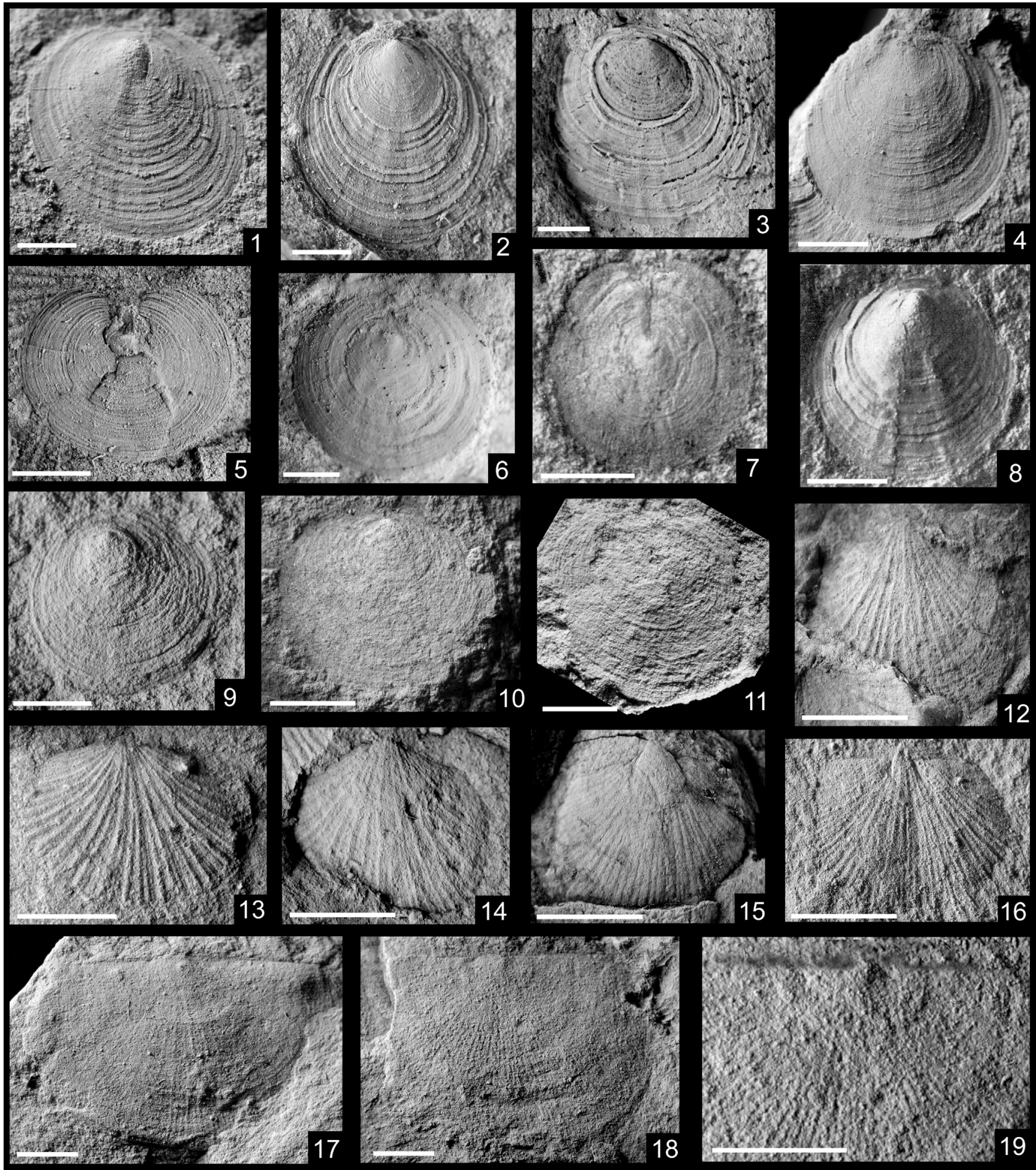

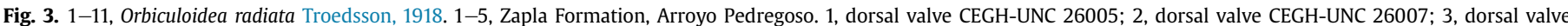

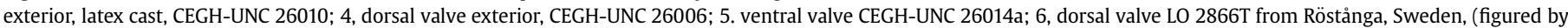

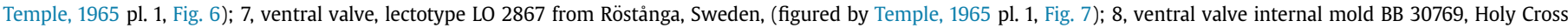

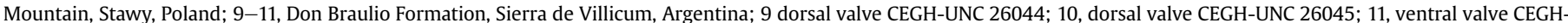

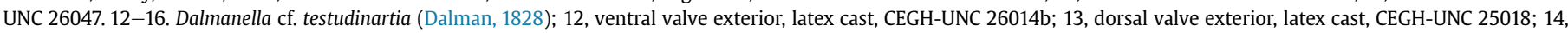

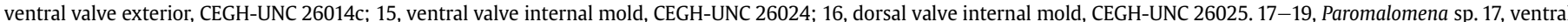

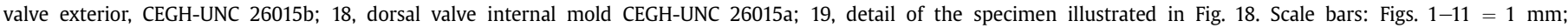
Figs. $12-19=5 \mathrm{~mm}$. 


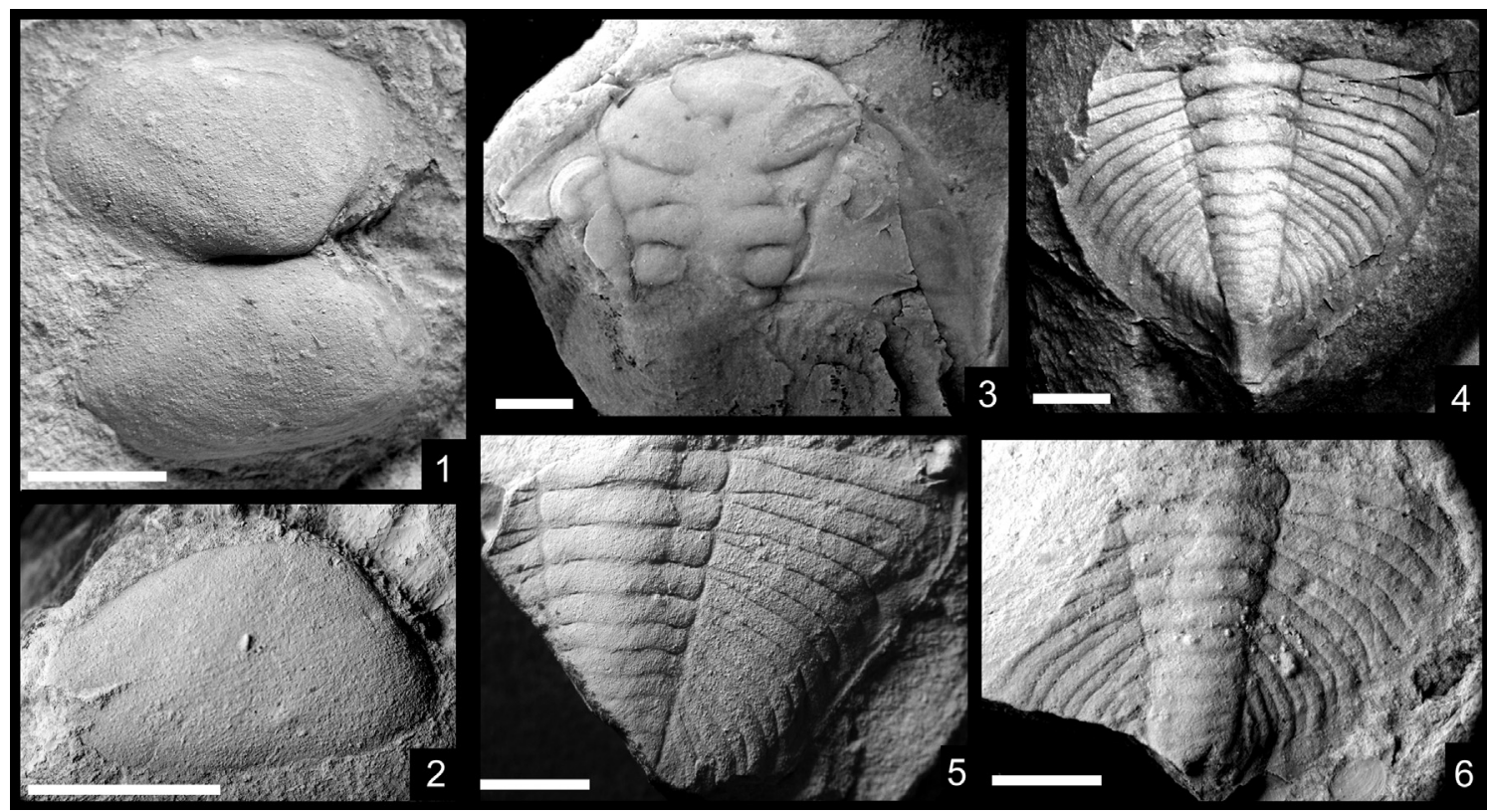

Fig. 4. 1-2, Modiolopsis? sp. 1, conjoided valves CEGH-UNC 26029; 2, right valve CEGH-UNC 26030. 3-6. Dalmanitina subandina Monaldi and Boso, 1987. 3, Cephalon, holotype CNS-I 094-1/654(1); 4, pygidium CNS-I 094-1/654(2); 5, incomplete pygidium CEGH-UNC 26015c; 6, pygidium CEGH-UNC 26016. Scale bars $=5$ mm.

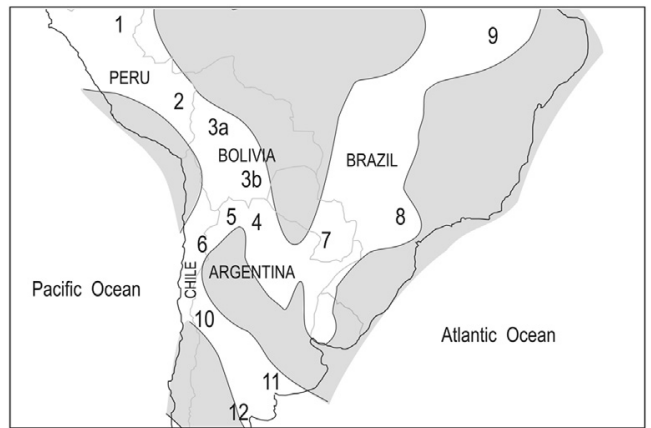

Fig. 5. Lower Paleozoic basins of southern South America and localization of the stratigraphic sections illustrated on Fig. 6 and 7 (gray: emerged areas). 1-5: Central Andean Basin; 1, southern Peru; 2, Bolivia (Tarija region); 3, Sierra de Santa Bárbara (Subandean Ranges); 4, Cordillera Oriental (Los Colorados); 5. western Puna (Salar del Rincón). 6, Puna region; 7, Paraná Basin (Paraguay and Brazil); 8, Paranaiba Basin; 9, Amazonas Basin; 10, Precordillera Basin; 11, Tandilia System; 12, North Patagonian Massif.

here in Fig. 3.6-3.8). The muddy interval of the Don Braulio Formation has yielded a few specimens of a discinid closely similar to 0 . radiata in size, ornament, valve convexity and position of the umbo, and they are therefore regarded tentatively as conspecific (Figs. 3.9-3.11).

Order ORTHIDA Schuchert and Cooper, 1932

Superfamily DALMANELLOIDEA Schuchert, 1913

Family DALMANELLIDAE Schuchert 1913

Genus Dalmanella Hall and Clarke, 1892

Type species: Orthis trestudinaria Dalman, 1828. Upper Ordovician (Hirnantian) Dalmanitina Beds, Loka Formation, Borenshult, Östergötland, south Sweden.

Dalmanella cf. testudinaria (Dalman, 1828)

Fig. 3.12-3.16.

Material: Three ventral valves and four dorsal valves, CEGH-UNC 26014, 26018, 26022-26026 from the Zapla Formation, Sierra de Santa Bárbara (Arroyo Pedregoso), Jujuy Province, Argentina.

Remarks: The material from the Zapla Formation consists of several exteriors of both valves and some poorly preserved interiors preventing a more conclusive specific identification. The Zapla specimens are assigned to Dalmanella on the basis of their ventribiconvex shell, weakly fascicostellate ornament, short diverging dental plates becoming subparallel anteriorly bounding a cordate muscle field, and small bilobed cardinal process. The taxonomic value of the ribbing style has been emphasized by Jin and Bergström (2010) who noted that the 'true' D. testudinaria have a dorsal medial interspace delimited by a pair of symmetrical primary costae originated near to the umbonal region and branched anteriorly. The dorsal medial interspace between them corresponds to a median costa in the ventral valve. Also typical of $D$. testudinaria is the weakly bundled fascicostellae radial ornament averaging 3 costellae per $1 \mathrm{~mm}$ at the anterior margin. All of these features have been observed in our material but details of microperforations (punctae, aditicules) are not preserved. D. testudinaria is one of the more distinctive taxa of the typical Hirnantia Fauna (Rong and Harper, 1988; Rong et al., 2002, and references therein).

Order STROPHOMENIDA Öpik, 1934

Superfamily STROPHOMENOIDEA King, 1846

Family GLYPTOMENIDAE Williams, 1965

Genus Paromalomena Rong, 1984.

Type species: Platymena polonica Temple, 1965. Upper Ordovician Dalmanitina Beds, (Hirnantian), Stawy, Holy Cross Mountain, Poland.

Paromalomena sp.

Fig. 3.17-3.19.

Material: One ventral valve CEGH-UNC 26015a, one dorsal valve CEGH-UNC 26015b from the Zapla Formation, Sierra de Santa Bárbara (Arroyo Pedregoso), Jujuy Province, Argentina.

Remarks: The gently convex, non geniculate ventral valve, nearly plane semicircular dorsal valve, finely multicostellate radial ornament crossed by irregular concentric rugae, short widely divergent sockets ridges, and weak notothyrial platform are all features suggestive of Paromalomena. The Zapla specimens are left under open nomenclature due to the paucity of material. The only species ascribed to this genus is the widespread $P$. polonica (Temple), a core taxon of the Hirnantia Fauna. In Argentina, 


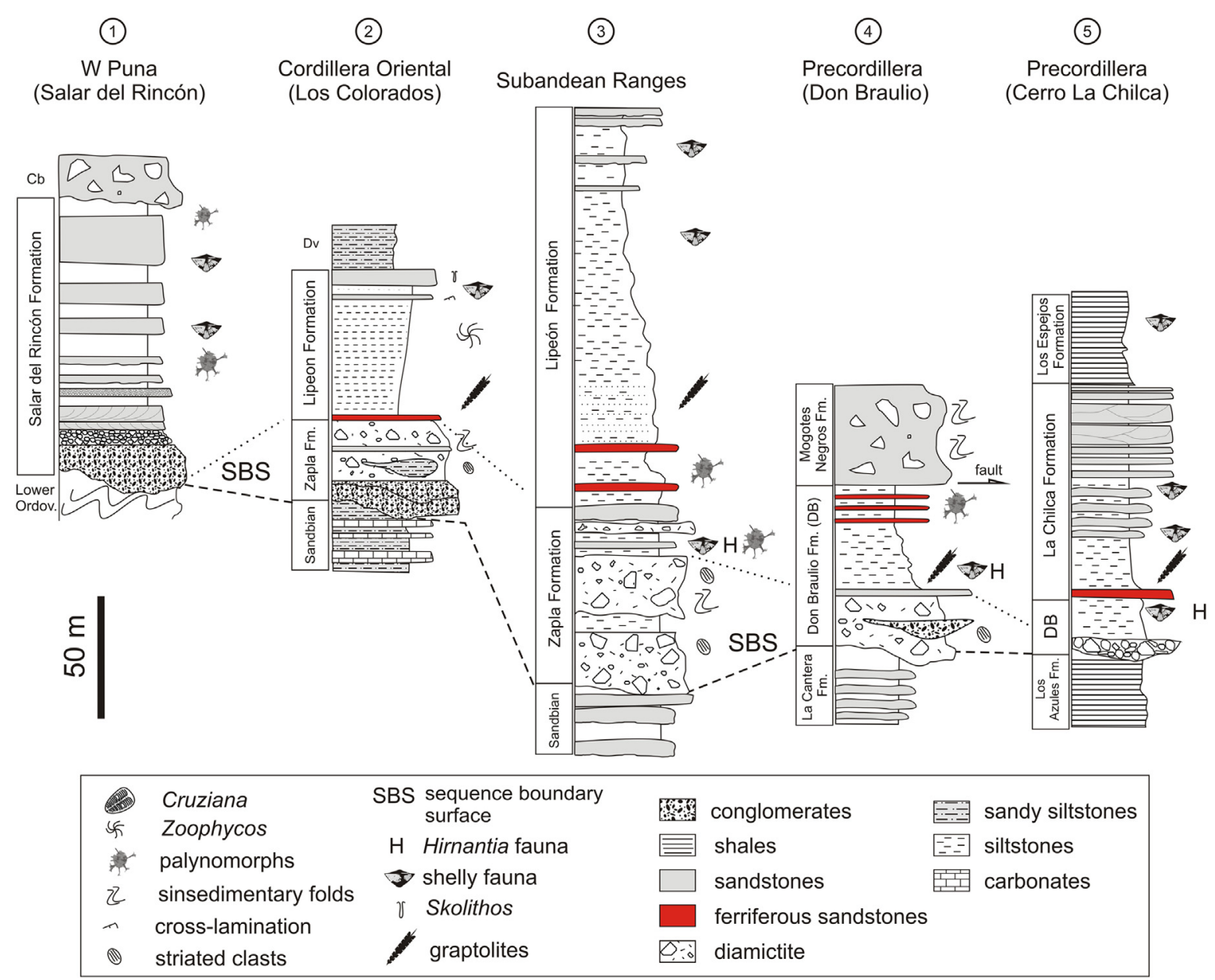

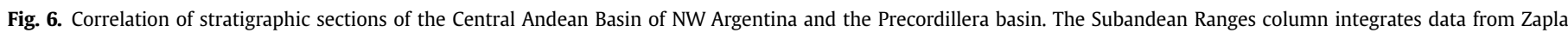
anticline and Sierra de Santa Bárbara. SBS: Sequence boundary surface.

P. polonica is very common in the Don Braulio Formation (Benedetto, 1990; Astini and Benedetto, 1992).

\subsection{Bivalves}

Order MYTILIDA Férussac, 1822

Superfamily MODIOLOPSOIDEA Fisher, 1886

Family MODIOLOPSIDAE Fisher, 1886

Genus Modiolopsis Hall, 1847

Type species: Pterinea modiolaris Conrad, 1838. Upper Ordovician, New York, U.S.A.

Modiolopsis? sp.

Fig. 4.1-4.2.

Material: One conjoined specimen and two right valves CEGHUNC 26028-26030 from the Zapla Formation, Sierra de Santa Bárbara (Arroyo Pedregoso), Jujuy Province, Argentina.

Remarks: Available specimens are scarce but well preserved. In the conjoined specimen illustrated in Fig. 4.1 there is no trace of teeth, placing this species among the edentulous modiolopsids and refer it tentatively to Modiolopsis. The shell outline is suboval with a posteriorly directed rounded carina and a very shallow, almost inconspicuous ventral sinus; the umbo is prosogyrate and curved on the hinge plane, and it is situated towards the anterior third of shell. The valve exterior is essentially smooth with fine growth lines only. Modiolopsis cuyana Sánchez, 1990, from the Hirnantian Don Braulio Formation, differs from the Zapla specimens in its strongly expanded posteriorly shell profile and in the subterminal position of the umbo.

\subsection{Trilobites}

Order PHACOPIDA Salter, 1864

Superfamily DALMANITOIDEA Vodges, 1890

Family DALMANITIDAE Vodges, 1890

Genus Dalmanitina Reed, 1905

Type species: Phacops socialis Barrande, 1846. Upper Ordovician of Bohemia.

Discussion: The relationships between the sister genera Mucronaspis Destombes, 1963, and Dalmanitina Reed, 1905 constitute a persistent and unsolved systematic problem (Owen, 1986, Owen et al., 1991; Waisfeld and Vaccari, 2003; Zhou et al., 2012; Hints et al., 2012). According to Owen (1981), Mucronaspis can be distinguished from Dalmanitina on the basis of a set of morphological features including a less convex cephalon, less swollen glabella, longer genal spines, posterior branch of the facial suture cutting lateral margins of the cephalon at about the level of the posterior border furrow, larger eyes, subparallel S1 and S2, S2 well incised only adaxially, S3 less divergent anteriorly, posterior margin of hypostome denticulate, thoracic pleurae extending into long pointed tips, and pleural ribs of the pygidium more curved and more rearward directed posteriorly. Despite these features, the wide morphological variation and the combination of characters in 
(6)

Southern Bolivia
(7)

$$
\text { Paraguay }
$$

(Paraná Basin)

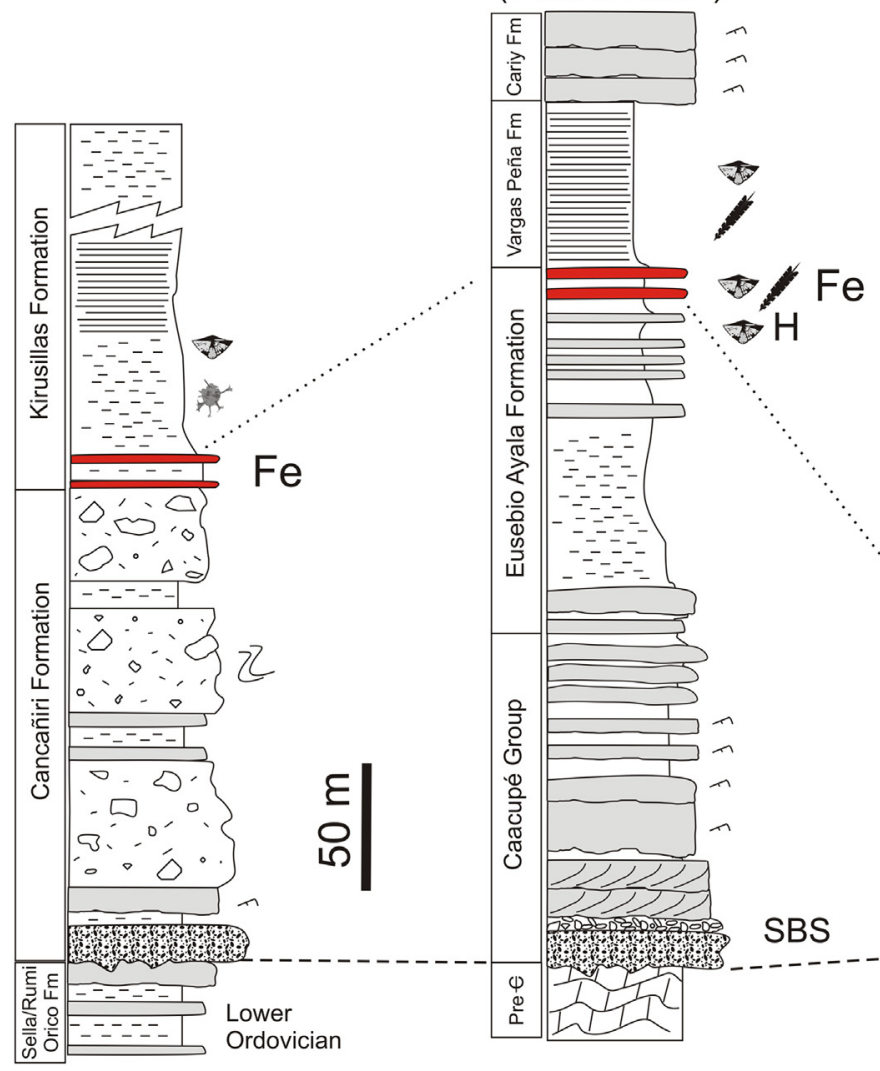

(9)

South Africa (Cape Basin)
(Paraná Basin)

Fig. 7. Correlation of stratigraphic sections of southern Bolivia (Tarija area), Paraná Basin (Paraguay and Brazil), and Cape Basin of South Africa. References the same as Fig. 6.

species belonging to both genera obscure their identity (Hints et al., 2012). Recently, in an attempt to unravel this topic, Zhou et al. (2012) studied a group of species related to 'mucronata' and many of the Dalmanitina or Mucronaspis species were transferred to Mucronaspis (Songxites) Lin, 1981. However, the systematics of these dalmanitids is far from being solved and both genera are in need of a global revision. Thus, following its original designation, and to avoid more confusion in the literature, we refer the Zapla species to Dalmanitina.

Dalmanitina subandina Monaldi and Boso, 1987.

Fig. 4.3-4.6.

Material: One cephalon, CNS-I 094-1/654 (1), and four pygidia CNS-I 094-1/654 (2), CEGH-UNC 26015c, 26016, 26017 from the Zapla Formation, Sierra de Santa Bárbara (Arroyo Pedregoso), Jujuy Province, Argentina.

Remarks: Isolated cephala, pygidia, and free cheeks were initially reported from the upper strata of the Zapla Formation in the Sierra de Santa Bárbara by Monaldi and Boso (1987) and later, the type material was re-illustrated by Waisfeld and Vaccari (2003). The record of well preserved Dalmanitina suggests a Hirnantian age for these beds. The pygidia from the Zapla Formation resemble those of Mucronaspis? sudamericana Baldis and Blasco, 1975, from the Precordilleran Don Braulio Formation of Hirnantian age, but their cephala differ in the smaller size of the eyes and the shorter genal spines (Waisfeld and Vaccari, 2003). Unlike the Zapla assemblage, the Precordilleran trilobite association also includes Eohomalonotus villicumensis Baldis and Blasco, 1975, and Eoleonaspis? Sheng, 1974 (Halpern et al., 2014).

\section{Age of the Zapla/Cancañiri diamictite}

\subsection{The Zapla Formation}

When Schlagintweit (1943) proposed the name Zapla Glacial Horizon he considered this unit to be 'Gotlandian' (=Silurian) in age based on its stratigraphic position above 'Skiddavian' (=Lower Ordovician) quartz-arenites and below a thick succession of micaceous shales and sandstones bearing 'Devonian' shelly faunas. Subsequent paleontological studies demonstrated that the Schlagintweit's inference was essentially correct, as the underlying Capillas/Centinela Formations (and the correlative San Benito Formation of Bolivia) are Sandbian to early Katian in age (Suárez Soruco and Benedetto, 1996; Sánchez and Astini, 2011; Benedetto, 2013), and the overlying richly fossiliferous Lipeón Formation is Silurian.

Autochthonous (non resedimented) fossils within the glacial diamictite are scarce, probably due to a combination of unfavorable environmental factors (e.g. non marine sediments), physiochemical conditions (partially anoxic bottoms), and taphonomic conditions (coarse-grained gravity mass flows). To date, in situ macrofossils have been found only in the upper part of the Zapla Formation, including the trilobite D. subandina Monaldi and Boso (1987) and the brachiopods and bivalves described in this paper. On the basis of the record of Dalmanella cf. testudinaria and Paromalomena sp. the Zapla shelly fauna may be ascribed to the Hirnantia Fauna. It is interesting to note that Brockmann et al. (1972) mentioned in their geologic study of the Chapare area, in the central Subandean 


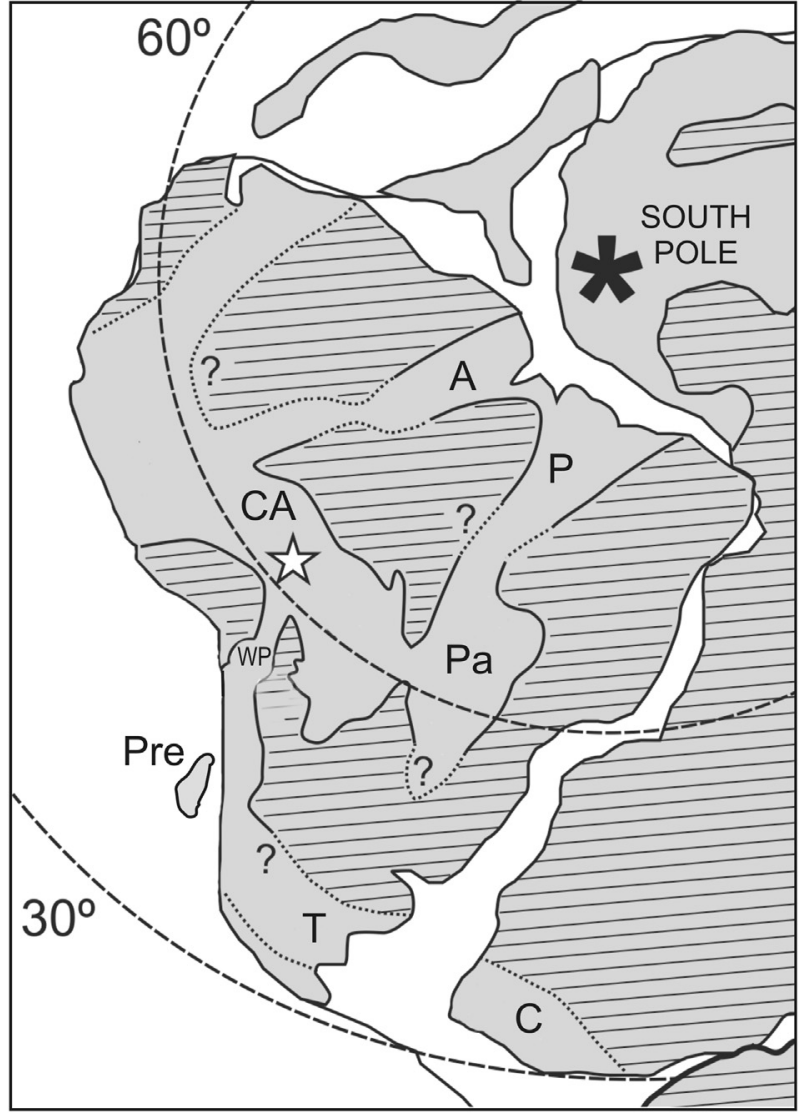

Fig. 8. Paleogeographic reconstruction showing location of basins mentioned in the text (modified from Benedetto et al., 2013).

Ranges of Bolivia, the brachiopod Schizophoria? sp. from the Cancañiri Formation exposed between the $\mathrm{km} 99$ and 100 of the road Coroico-Villa Tunari. Fossils come from a bed of bioturbated siltstones interbedded within a $\mathrm{ca} .20 \mathrm{~m}$ thick succession of poorly stratified diamictites, which are sharply overlain by organic matterrich shales bearing monograptid graptolites and the trilobite Leonaspis (s.l.). One of the authors (JLB) had the opportunity of revising a Schizophoria? Specimen housed in the Yacimientos Petroliferos Fiscales Bolivianos (YPFB) collection at Santa Cruz de la Sierra concluding that undoubtedly it belongs to Hirnantia, and very probably to Hirnantia sagittifera (Benedetto et al., 1992). Unfortunately, this material has never been described nor illustrated. The occurrence of Hirnantia in the Cancañiri diamictite is consistent with the fauna described herein and corroborates the presence of a low diversity Hirnantia fauna in the diamictite of both localities. As it is widely known, the Hirnantia-Dalmanitina fauna is a worldwide brachiopod-trilobite assemblage that characterizes the uppermost Ordovician Hirnantian Stage (Lespérance, 1974; Owen et al., 1991; Rong and Zhan, 2006; Amstrong, 2007; Hints et al., 2012; among others). Although the majority of last occurrences of this fauna have been documented within the upper Hirnantian Normalograptus persculptus Biozone, in a few sites (e.g. Gizhou in South China, Lake District in England) representatives of the Hirnantia-Dalmanitina fauna persist into the very basal Llandovery (lower part of the Parakidograptus acuminatus Biozone) (Rong et al., 2002; Harper and Williams, 2002).

The Hirnantian age of the Zapla Formation has been further corroborated in the Río Capillas stratigraphic section of the Sierra de Zapla by the record of a chitinozoan species comparable to
Spinachitina oulebsiri Paris et al. (de la Puente and Rubinstein, 2013; pl. 2, Fig. 2), which in northern Gondwana indicates the late Hirnantian, but possibly reaches the earliest Rhuddanian (Vandenbroucke et al., 2009). This species is associated with wellpreserved specimens of Desmochitina minor typica Eisenack (de la Puente and Rubinstein, 2013; pl. 2, Fig. 1), a classical component of the Late Ordovician of northern Gondwana with its LAD in the late Hirnantian (Paris et al., 2015). S. oulebsiri has been identified in the glacially-related Second Bani Formation of the Moroccan AntiAtlas, where it indicates the uppermost Ordovician chitinozoan biozone (Loi et al., 2010). These beds contain representatives of the Hirnantia Fauna (Sutcliffe et al., 2001). The Zapla Formation also yielded a palynomorph assemblage dominated by Villosacapsula, Eupoikilofusa, Neoveryhachium, Polygonium, Myrchistidium, and Multiplicisphaeridium, corroborating a Late Ordovician age (Rubinstein and de la Puente, 2008). This evidence, however, does not fit with the chitinozoans described by Grahn and Gutiérrez (2001) from samples collected in the Río Capillas and Arroyo Los Matos sections of the Sierra de Zapla, which indicate a Silurian age (not older than Aeronian) for the upper part of the Zapla Formation. That age is contradictory not only with the above mentioned fossils but also with the Rhuddanian graptolite assemblage recovered from the base of the overlying Lipeón Formation (Rickards et al., 2002). We support here the interpretation by de la Puente and Rubinstein (2013) that those levels sampled by Grahn and Gutiérrez (2001) belong actually to the Lipeón Formation and not to the Zapla Formation. In fact, lithology of the sampled beds ('darkgray to brownish-yellow quartzitic sandstones') is suggestive of the lower yellowish sandstones of the Lipeón Formation, whilst the overlying micaceous sandstones and mudstones probably correspond to the upper member of this unit. Also striking is the absence in the successions studied by Grahn and Gutiérrez (2001) of ironstone beds, which are present at or near the contact between the Zapla and Lipeón formations throughout the Zapla Range (Boso and Monaldi, 2008).

Recently, late Katian-Hirnantian chitinozoans have been recovered from the glacially-related deposits of the Caspalá Formation, an equivalent of the Zapla Formation at the eastern margin of the Cordillera Oriental (Rubinstein et al., 2015). The late Katian species from this unit, such as Tanuchitina cf. fistulosa Taugourdeau and de Jekhowsky, have been frequently recorded in northern Gondwana (Paris et al., 2015, and references therein). Their presence in the Caspalá Formation has been interpreted as a recycled association during the Hirnantian glacial pulses.

As stated above, the age of the Zapla diamictite is further constrained by the fauna from the immediately overlying Lipeón Formation. The graptolites recovered from the lower member ('yellowish sandstones') at the Zapla anticline (9 de Octubre Mine section) and Sierra de Puesto Viejo are indicative of the lowest Llandovery P. acuminatus Biozone (Rickards et al., 2002). The association consists of Talacastograptus leanzai Cuerda, Rickards and Cingolani, Normalograptus rectangularis (McCoy), Clinoclimacograptus sp., and Metaclimacograptus? robustus Cuerda (Monteros et al., 1993; Moya and Monteros, 1999; Rickards et al., 2002). The middle and upper parts of the Lipeón Formation have yielded diverse brachiopod, trilobite, and bivalve faunas ranging in age from late Llandovery to Pridolian (Sánchez, 1989, 1991; Benedetto, 1991; Waisfeld and Sánchez, 1993). Evidence from chitinozoans also points to a Llandovery age for the base of the Lipeón Formation at the Zapla Range. On the basis of the occurrence of Margachitina margaritana (Eisenack) and Salopochitina monterrosae Cramer, Grahn and Gutiérrez (2001) assigned the lower part of the Lipeón Formation at the Río Capillas section to the upper Llandovery (Telychian)-lower Wenlock (Sheinwoodian). de la Puente et al. (2012) and de la Puente (2014) reported for the first time 
chitinozoans of Rhuddanian, Aeronian and Telychian age from the base of the Lipeón Formation at the Río Capillas of the Sierra de Zapla. The basal Lipeón Formation contains a large species of Spinachitina that probably correspond to Spinachitina fragilis (Nestor, 1980) (de la Puente et al., 2012), which is one of the diagnostic chitinozoans for the early Rhuddanian in most of the northern Gondwana regions, known from the A. ascensus and P. acuminatus biozones (Paris et al., 2015, and references therein). In the Caspalá are the Lipeón Formation contains Telychian chitinozoans, which correlate to the associations from the lower (but not basal) Lipeón Formation cropping out in the Subandean Ranges (Rubinstein et al., 2015).

\subsection{The Cancañiri/San Gabán formations}

Since the first palynological data (mostly unpublished) provided by paleontologists of Yacimientos Petrolíferos Fiscales Bolivianos (e.g. Lobo et al., 1976), the age of the Cancañiri Formation of Bolivia has been regarded as essentially Silurian. More specifically, palynomorphs from this unit have been referred to the Helios aranaides/ Duvernaysphaera gothica Biozone of Llandovery age (Liachenko and Pérez Leytón, in Limachi et al., 1996). Acritarchs from other sections of the Cancañiri Formation (e.g. Río Blanco in the Potosí area), however, pointed to a rather Late Ordovician than Early Silurian age (Gagnier et al., 1996), in accordance with the above mentioned record of Hirnantia in the Chapare region. The trilobites and brachiopods described by Antelo (1973) from the Pojo and Lampaya sections are in need of revision, but the fauna is undoubtedly Silurian (Laubacher et al., 1982; Benedetto and Suárez Soruco, 1998). These fossiliferous strata, however, do not belong to the Cancañiri Formation but to the lower part of the Kirusillas Formation (Benedetto et al., 1992) or the Llallagua Formation (Laubacher et al., 1982). Correlative strata, formerly referred to the Cancañiri Formation (Anaya et al., 1987; Suárez Soruco, 1995), are well exposed along the Sikhiri River in the Cordillera del Tunari, west of Cochabamba. These beds contain a rich brachiopod assemblage of Wenlock age displaying strong affinities with the Precordilleran faunas (Los Espejos Formation), sharing Australina, Dedzetina (Notodedzetina), Harringtonina, Leangella, and probably Amosina (Benedetto and Suárez Soruco, 1998). As Díaz-Martínez and Grahn (2007) demonstrated, these fossiliferous mudstones correspond to the lower part of the Kirusillas Formation. In the Cordillera del Tunari and in the Chapare region (central Subandean Ranges) a distinctive cool-water, temperate carbonate bed (the Sacta Limestone) of $1-3 \mathrm{~m}$ in thickness contains poorly preserved macrofossils (corals, brachiopods) and conodonts of early Wenlock age (Sheinwoodian) (Merino, 1991). This carbonate unit, that was regarded by Montaño (1994) as a member of the Kirusillas Formation, has been interpreted as deposited on the stable margin of the deep, strongly subsiding foreland basin developed to the west during the Llandovery and Wenlock (Díaz-Martínez, 2007). Although the presence of resedimented limestone slabs in the Cordillera del Tunari has been mentioned by Díaz-Martínez (2007) as supporting a Sheinwoodian glaciation, conclusive field evidence of glacial deposits of such age is lacking.

New evidence supporting the Silurian age of the Cancañiri diamictite was provided by Díaz-Martínez and Grahn (2007) who reported scattered and poorly preserved chitinozoans from La Cumbre, north of La Paz (Belonechitina cf. postrobusta, Cyathochitina sp., and Conochitina cf. elongata) suggesting a Rhuddanian to early Aeronian age. A similar age was inferred by Vavrdová et al. (2011) for the San Gabán diamictite exposed along the Inambari River in southern Peru on the basis of a low diverse palynomorph association.

\section{Hirnantian vs. Silurian age of diamictites}

In order to account for the inconsistency of the Silurian age of the Cancañiri/San Gabán formations in northern Bolivia/southern Peru, and the Hirnantian age of the Zapla glacial diamictite in northwestern Argentina, two different -but probably complementary- hypotheses are evaluated: a tectonosedimentary hypothesis and a paleoclimatic hypothesis.

The first hypothesis states that under the name 'Cancañiri Formation' at least two genetically different types of diamictites have been included (a) true glacial diamictites recording different subenvironments, e.g. subglacial till, supraglacial debris, glaciofluvial and glacimarine deposits; and (b) gravity-flow deposits unrelated with, or indirectly related to, glacial activity, ranging from finegrained turbidites interbedded with open marine platform muds, to coarse debris flows including olistolith-sized blocks coming from underlying units (e.g. Sandbian quartzite slabs over $20 \mathrm{~m}$ long), embedded in a matrix contorted by slump folds. Similar rocks exposed in southern and southeastern Peru have been referred to as the San Gabán Formation, which consists of boulders of variable composition including some faceted and striated clasts, as well as large sandstone slabs immersed in a muddy matrix. According to Díaz-Martínez et al. (2001) the Peruvian successions resulted from the superposition of several gravity-induced sedimentary events alternating between background marine sedimentation. A similar explanation was already proposed by González et al. (1996) and further discussed by Díaz-Martínez and Grahn, 2007, p. 75 who suggested that the Cancañiri diamictite and the lower 'diamictite' of the Kirusillas Formation may represent separate resedimentation events of different provenance.

Evidence against a glacial origin of the above mentioned successions of Bolivia and Peru are the following: (1) the great thickness of the pebbly mudstones (up to $750 \mathrm{~m}$ near to the depocenter), which largely exceeds that recorded in glacimarine environments, and (2) the presence within the diamictite of huge olistolith-sized slabs that are unknown in glacigenic environments. It has been argued that such olistostromes and associated turbidites accumulated in a deep-marine trough supplied from the fault-bounded, tectonically active western margin of the foreland basin (Egenhoff et al., 1999; Egenhoff, 2003). Resedimented boulders of glacial origin are occasionally present in such olistolith-bearing units. Deformational events leading to the accumulation of these thick successions have been related to the rotation of the Arequipa-Antofalla continental block (Forshite et al., 1993; Erdtmann and Suárez Soruco, 1999). According to Sempere (1995) the strongly subsident trough of the Bolivian Central Andes originated by tectonic loading of the craton linked to subduction-related transpressional stress. The uplift of the proto-Puna along the Antofalla segment is distinguished by an interruption of sedimentation during the Sandbian/Katian (Ocloyic Orogeny) and the migration of the foreland basin to the east (Ramos, 2008 and references therein). These units are to some extent comparable both lithologically and genetically to the Rinconada Formation of the Precordillera belt, which consists of strongly deformed debris-flow deposits formerly described as a 'tectonic mélange' by Heim (1948) - containing huge, over $100 \mathrm{~m}$ long tabular olistoliths of Lower-Middle Ordovician platform limestones together with boulders of different sizes and lithologies (quartzites, conglomerates, metamorphic rocks), all embedded in a matrix with slump folds (Gosen et al., 1995). Glacially striated pebbles have been mentioned from the upper part of the Rinconada Formation (Keidel, 1939; Gosen et al., 1995). To the south, in the Sierra de Villicum, a very similar olistostrome named the Mogotes Negros Formation overlies tectonically the glacigenic Don Braulio Formation (Fig. 6). The basal levels of the Mogotes Negros Formation contain striated clasts and 
fossiliferous slabs bearing Hirnantia fauna. On the basis of the resedimented fossiliferous boulders, the age of Precordilleran olistostromes is Silurian to Early Devonian, but the precise age of sedimentation remains to be established (cf. Peralta, 2007). The origin of the Rinconada/Mogotes Negros Formation has been linked alternatively to the accretion of the Chilenia terrane (Ramos et al., 1986; Thomas and Astini, 2003), post-collision relaxation after the Precordillera-Gondwana docking (Astini et al., 1995), rifting (from Laurentia?) along the eastern margin of the Precordillera (Gosen et al., 1995), or strike-slip deformation of a remnant basin during the final phase of the Precordillera accretion (Benedetto, 2004).

In the light of this 'tectonosedimentary' hypothesis, the more likely scenario is that of a coast covered by tillites and proglacial sediments deposited during the retreat of glaciers by the end of the Hirnantian. These emergent, weakly lithified glacigenic deposits were reworked and redistributed by high-energy wave- or stormdominated processes prevailing during the postglacial transgression, and afterwards partly incorporated to gravity flows and resedimented in the deep basin, which explain the presence of scattered striated and faceted clasts within the debrites and their association with deep-water turbidites. Almost simultaneously, large boulders and a great amount of detritus may have been shed into the basin by rock fall, sliding and slumping from the tectonic highs. In the light of this hypothesis, the Lower Silurian chitinozoans reported by Díaz-Martínez and Grahn (2007) and acritarchs and prasinophytes reported by Vavrdová et al. (2011) dating the gravity flows containing glacial boulders rather than the glaciation. As Díaz-Martínez and Grahn (2007, p. 73) stated “... its original relation to glaciers, and the time lapse before resedimentation are not known".

The paleoclimatic hypothesis stated that glaciated highlands (probably mountain glaciers) persisted in some regions during the Early Silurian supplying glacigenic material to the marine basin. Data from clumped isotope paleothermometry from Laurentian carbonates revealed that after the peak of glaciation in the Hirnantian relatively low temperatures and moderate polar ice sheets persisted during the Rhuddanian and the first half of the Aeronian (Finnegan et al., 2011) and stratigraphic evidence (forced regressions) from Antocosti Island suggest glacial activity until the early Telychian (Desrochers et al., 2010). In this frame, it can be assumed that the glacigenic sediments within the Cancañiri/San Gabán formations were generated during the last stages of the glaciation and their recycling in deeper waters was virtually synchronous with the glaciation. If correct, palynomorphs recovered from the matrix of diamictites indicate the presence of relict ice sheets in the area by the Early Silurian. Following this reasoning, the Ludlow shales of the Ananea Formation that in southern Peru cover the San Gabán diamictite (Vavrdová et al., 2011) should reflect the postglacial sea-level rise.

On balance, we consider that available data favor the tectonosedimentary hypothesis for the genesis of Bolivian/Peruvian diamictites. Although during the poleward retreat of the ice sheet some glaciated areas could have persisted in the Central Andean region during the Early Silurian, the enormous volume and the great thickness of diamictites accumulated in this basin hardly can be attributed purely to glacial action. But if it was, there is not a convincing explanation for the complete absence of glacial action of that age in the neighboring Paraguayan and the NW Argentina subbasins (Fig. 5) in which a continuous upper HirnantianPridolian succession is preserved. This reinforces the idea that the San Gabán Formation represents one or more gravity flow events within open marine sedimentation. In turn, deposition of the Ananea shales can be better related to the deepening of the basin due to the extensional tectonics that opened the Peruvian Contaya
Basin (Erdtmann and Suárez Soruco, 1999) rather than to postglacial transgression. It is also striking the absence in these regions of ironstone beds that everywhere are associated with the base of the rapid postglacial transgression.

\section{Regional correlation of ironstone beds}

Oolitic ironstones are particularly abundant in Ordovician rocks formed at middle to high latitude regions of Gondwana and periGondwanan terranes (Van Houten, 1985). Iron-rich horizons have been recognized in many southern South American basins (Fig. 5) reflecting large-scale eustatic and paleoclimatic fluctuations around the Hirnantian/Llandovery boundary useful for their correlation (Figs. 6 and 7).

In the Subandean Ranges a first ironstone interval ranging from 1 to $10 \mathrm{~m}$ in thickness developed at the base of the Lipeón Formation, immediately above the Zapla glacial diamictite, and a second horizon of similar thickness is usually present some tens of meters above the first one (Fig. 6). The two main ironstone beds are separated by bioturbated yellowish to reddish wackes. Although the thickness, mineralogy and texture of the ironstones are quite variable regionally, in general they are made by an alternation of hematitic and chamoisitic beds. The facies dominated by peloids and ooids, hematite intraclasts, and well-sorted and rounded quartz grains with large scale trough and planar cross bedding has been interpreted by Boso and Monaldi (2008) as originated along the crest of shallow shelf ridges. The chamoisite peloidal wackeironstone facies characterized by smaller size predominantly chamoisitic allochems, often associated with flaser and wavy bedding, is interpreted by these authors as generated on the slopes of bars in low-energy and slightly dysoxic conditions. These beds grade upwards and laterally to platform bioturbated sandstones and mudstones bearing Zoophycus and Chondrites.

Schönian (2003) and Schönian and Egenhoff (2007) studied to some detail the diamictites exposed in the Sella area, $20 \mathrm{~km}$ north from Tarija, which unconformably overlie the Lower Ordovician Sella and Rumi Orkho formations (Fig. 7). There, the top of the Cancañiri diamictite is overlain by one or two $2-15 \mathrm{~m}$ thick beds of ferruginous sandstones containing chamoisite ooids. According to these authors such ferruginous horizons generated in a brackish shallow marine environment during the transgression that took place after a subaerial exposure. These ironstone beds developed at the base of a $400 \mathrm{~m}$ thick succession of siltstones and fine-grained sandstones (Kirusillas Formation), in the same stratigraphic position that the above mentioned ironstones of the Zapla Range. Thus, the Cancañiri and Kirusillas formations of southern Bolivia are correlatable with the Zapla and Lipeón formations of the Subandean Ranges of NW Argentina, respectively (Benedetto et al., 1992; Schönian and Egenhoff, 2007) (Figs. 6 and 7). Of interest here is that in the depocenter area of the Cancañiri Formation located in the Altiplano (= Puna) and Cordillera Oriental of Bolivia, ironstone beds have not been reported from the overlying dark gray shales and sandstones (Llallagua/Uncia formations), suggesting that prevailing environmental conditions were different from those in the southern part of the basin.

In the western flank of the Cordillera Oriental of Argentina, at the Los Colorados locality, a 9-20 m thick glacial diamictite has been referred to as the Zapla Formation by Astini et al. (2004) (Fig. 6). The diamictite bears faceted and striated clasts of metamorphic rocks and fossiliferous mudstones redeposited from the underlying Sandbian strata. Glacial diamictites are interbedded with channelized cross-stratified sandstones capped by Skolithosrich sandstones. A conspicuous ferruginous horizon $\mathrm{ca}$. $1 \mathrm{~m}$ thick made of quartz arenites with hematitic cement lies in sharp contact above the diamictite. It is overlain by a quartz conglomerate 
followed by reddish and greenish graptolitic mudstones of MidLlandovery age (D. convolutus-S. sedgwicki Zones) (Toro, 1995; Rubinstein and Toro, 2006) and reddish-violet sandstones bearing a monotypic assemblage of Harringtonina sp. (Benedetto and Toro,1996).

Iron-rich deposits of Silurian age are known from many localities in the Precordillera of western Argentina (Peralta et al., 1986). The ironstone beds occur near the top of the Don Braulio Formation in the Villicum Range are of particular interest for the purpose of this paper as they occur a few meters above shallow-water marine mudstones bearing Hirnantia Fauna and $N$. persculptus, which in turn overlie a glacial diamictite of Hirnantian age (Levy and Nullo, 1974; Benedetto, 1986, 1990; Peralta and Carter, 1990; Peralta and Baldis, 1990; Buggisch and Astini, 1993; Astini, 1999, 2001). The upper $20 \mathrm{~m}$ of the Don Braulio Formation consist of dark gray (yellowish in weathering surface) bioturbated mudstones interbedded with scattered thin beds of fine-grained sandstone (Fig. 6). Towards the top there are one to three conspicuous sharp-based beds of oolitic ironstones ranging in thickness from 10 to $60 \mathrm{~cm}$, exceptionally reaching $1 \mathrm{~m}$. Ooids are mostly of chamoisite and to a lesser degree of goethite; phosphatic nodules, chert intraclasts and bioclasts are common. Ooidal laminae are interbedded with quartz arenites cemented with hematite (Astini, 1992). These ferruginous beds have been interpreted as deposited on the top of nearshore migrating bars formed during short-term variations of sea level (e.g. rapid regressions and transgressions) leading to alternating reduced and oxic conditions (Astini, 1992). However, the intercalation of relatively thin ironstones within open shelf muds lacking in situ benthic fauna, and the presence of intraclasts near the base of oolite beds is suggestive of storm transport of ooids from coastal banks (Van Houten and Bhattacharyya, 1982). The age of ferruginous beds has been constrained to the Rhuddanian on the basis of the graptolite Climacograptus aff. hughesi (Peralta, 1985), chitinozoans (Volkheimer et al., 1980), and a rich and rather diverse acritarch assemblage recovered from the interbedded mudstones (Pothe de Baldis, 1997).

Ferruginous beds have also been reported in the Cerro La Chilca area, about $60 \mathrm{~km} \mathrm{NW}$ of Sierra de Villicum (Fig. 6). In this Precordilleran locality, the bioturbated mudstones with Hirnantia Fauna are overlain by graptolitic mudstones interbedded with three horizons some centimeters thick of ferruginous sandstones corresponding to the base of the La Chilca Formation (Astini and Benedetto, 1992). They consist of bioturbated fine-grained quartzsandstones and mudstones with hematitic and ankeritic cement bearing Thalassinoides and Chondrites burrows often filled with peloidal hematite (Bosio, 2000). A few hundred meters to the north of Cerro La Chilca the Hirnantian mudstones pinch out and the transgressive surface associated with ferruginous beds lies directly on Sandbian black shales (Los Azules Formation). The graptolite Lagarograptus sp. recovered from these levels indicates a Rhuddanian age. In other localities where the La Chilca Formation lies unconformably upon Middle Ordovician limestones (e.g. Talacasto, Gualilán) it starts with a thin chert conglomerate containing reworked ferruginous oolites. The flooding surface is slightly diachronous through the Precordillera basin, ranging in age from late Hirnantian (N. persculptus Biozone) (Cuerda et al., 1988) to early Rhuddanian (P. acuminatus-A. atavus biozones) (Rickards et al., 1996; Benedetto, 1995; Benedetto and Cocks, 2009; Toro et al., 2014), which can be due to the complex topography inherited from the collision of the Precordillera terrane against the South American margin of Gondwana (Astini et al., 1995; Benedetto, 2004). The presence of the endemic genus Talacastograptus in the basal levels of both La Chilca and Lipeón formations is significant as it confirms the correlation of the Precordilleran and Subandean ferruginous beds.
The Sierra Grande Formation in the North Patagonian Massif contains the southernmost (in present coordinates) extensive ferruginous deposits of South America. This unit rests unconformably above metamorphic basement rocks. The two main levels of oolitic ironstone are interbedded with mudstones, wackes, and quartz sandstones deposited in a storm- and wave-dominated shallow platform (Spalletti et al., 1991). Although this unit has yielded poorly preserved shelly faunas of undifferentiated Silurian/Early Devonian age, new collections studied by Siccardi et al. (2014) revealed the presence of the trilobite Eoleonaspis sp. and the brachiopods Eostropheodonta chilcaensis aff. parvula Benedetto (in Benedetto and Montoya, 2015), Heterorthella sp. and Dalmanella sp., supporting a correlation with the Rhuddanian Heterorthella precordillerana Assemblage, the lowermost fauna from the La Chilca Formation (Benedetto, 1995; Benedetto and Cocks, 2009). Such faunal similarities also indicate a connection between the north Patagonian and Precordilleran basins (Fig. 5).

\section{Age and extent of the postglacial transgression}

As a result of melting of the large Late Ordovician polar ice cap, the Ordovician/Silurian transition was a time of an unprecedented flooding of land masses (Cherns and Wheeley, 2009; Loi et al., 2010, and references therein). In South America, the sea penetrated deeply into the low relief cratonic areas of Brazil and Paraguay (e.g. Amazonas, Parnaiba, and Paraná basins) for the first time in the Phanerozoic (Berry and Boucot, 1973; Benedetto et al., 2013). The sea reached as far as the Puna region of Argentina and Chile and the North Patagonian Massif of southern Argentina covering peneplanized continental areas (Fig. 5). The timing of the postglacial sea level rise is useful evidence to constrain the end of glacial maximum. In the western Puna region of Argentina, for instance, the succession referred to as the Salar del Rincón Formation starts with lenticular conglomerates and cross-bedded fine to medium sized sandstones truncating folded Lower Ordovician volcanosedimentary rocks (Fig. 6). These beds have been interpreted as deposited in low sinuosity anastomosing fluvial channels (Donato and Vergani, 1985). We consider these erosive-based deposits as the infill of incised valleys formed during the lowstand phase at the peak of glaciation. The transgressive systems tract initiates with a tabular conglomerate succeeded by reddish siltstones and finegrained sandstones with ferruginous cement bearing trilobites, brachiopods, conularids, dendroid graptolites, and palynomorphs. The basal cryptospore assemblage indicates the Imperfectotriletes spp. Interval Biozone of late Hirnantian age, whereas acritarchs include both Late Ordovician and Early Silurian species (Rubinstein and Vaccari, 2004). The brachiopod fauna from the immediately overlying sandstones consists of Hindella crassa, Fardenia sp., and a species of Heterorthella comparable to the South African Heterorthella africana Cocks (Cocks, 1972), subsequently referred to Marklandella by Cocks and Fortey (1986). The assemblage suggests a latest Hirnantian to early Llandovery age (Isaacson et al., 1976; Benedetto and Sánchez, 1990). Chitinozoans from the Upper Member of the Salar del Rincón Formation in the Puna region (Fig. 6) record the transition of the latest Hirnantian (lower part of the Upper Member) to the lowermost Rhuddanian (upper part of the Upper Member) containing associations comparable with those in Northern Gondwana (de la Puente and Rubinstein, 2013; de la Puente, 2014; de la Puente et al., 2015).

About $150 \mathrm{~km}$ to the west, a closely comparable succession crops out in the southern part of the Salar de Atacama, northern Chile (Nyemeyer et al., 2010). This unit, named Quebrada Ancha Formation, starts with some tens of meters of quartz microconglomerate capped by a red coarse-grained sandstone layer, which in turn is overlain by reddish-brown siltstones and fine-grained calcareous 
sandstones bearing conularids and abundant brachiopods. As in the Argentine Puna, the fauna is dominated by Hindella crassa and it has been referred to the lower Llandovery (Nyemeyer et al., 2010).

The Central Andean Basin (Peru-Bolivia-NW Argentina-N Chile) is connected to the east by the vast intracratonic Paraná Basin, which extends through southern Brazil, Paraguay, Uruguay and northeastern Argentina (Fig. 5). Lower Paleozoic deposits are known from both the western (Paraguayan) and eastern (Brazilian) rims of the basin. In the Asunción area of Paraguay, the lowest sedimentary unit is the Caacupé Group (Harrington, 1950), which starts with conglomerates and massive or cross-bedded sandstones exhibiting sigmoidal cross stratification and mud drapes suggesting a fluvio-estuarine origin. This succession is conformably overlain by the Itacurubí Group, which has been divided into the Eusebio Ayala, Vargas Peña and Cariy formations (Harrington, 1972) (Fig. 7). The Eusebio Ayala Formation is a ca. $200 \mathrm{~m}$ thick succession of reddish sandstones grading upwards to fossiliferous fine-grained sandstones and siltstones interbedded with iron-rich beds. The abundance of Skolithos burrows and the presence of wavy and lenticular stratification indicates a lower subtidal to intertidal setting, whereas the shales and claystones of the overlying Vargas Peña Formation reveal the establishment of an open platform during the peak of the transgression (Benedetto et al., 2013). The Eusebio Ayala Formation has yielded a low diversity shelly fauna formerly attributed to the Silurian Clarkeia Fauna (Boucot et al., 1991). A recent revision, however, recognizes Arenorthis paranaensis Benedetto, Plectothyrella? itacurubiensis Benedetto, Eostropheodonta conradii (Harrignton), and Hindella sp. suggesting a Hirnantian age (Benedetto et al., 2013). Associated graptolites indicate a latest Ordovician to earliest Llandovery age (Cingolani et al., 2011; Alfaro et al., 2012) and the Ordovician/Silurian boundary probably lies within the upper part of the unit. The overlying Vargas Peña shales contain graptolites, trilobites, brachiopods, and palynomorphs supporting an Aeronian (D. convolutus - S. sedgwicki biozones) to early Telychian age, but a Rhuddanian age for the lowest horizons cannot be ruled out (Gray et al., 1992; Uriz et al., 2008; Tortello et al., 2008). It should be noted that glacial sediments are not exposed in the area, but a ca. $50 \mathrm{~m}$ thick tillite capped by sandstones and shales bearing Late Ordovician to Early Silurian palynomorphs has been reported from drill cores (Figueredo, 1995).

Along the eastern part of the Paraná Basin in Brazil (Fig. 5), the oldest Phanerozoic sedimentary rocks are represented by the Rio Ivaí Group, which rests unconformably above different basement units (Milani et al., 2007) (Fig. 7). The lower unit is the Alto Garças Formation consisting of a basal quartz conglomerate followed by cross-bedded sandstones of fluvial origin grading upwards to reddish Skolithos-bearing sandstones, which likely represent deposition in a coastal marine environment. They are sharply overlain by the laterally extensive Iapó diamictite of $c a .60 \mathrm{~m}$ in thickness. It is succeeded by the Vila María Formation, which consists of reddish ferruginous shales grading upwards to sandstones displaying hummocky cross stratification (Assine et al., 1994). Evidence from acritarchs, spores, chitinozoans, and graptolites indicates an early Llandovery age for the Vila María Formation (Gray et al., 1985, 1992; Misuzaki et al., 2002), whereas an $\mathrm{Rb}-\mathrm{Ar}$ age of $435.9 \pm 7.8 \mathrm{Ma}$ obtained from shales of this unit set the age around the Aeronian/ Telychian boundary. Consequently, it correlates with the Vargas Peña shales of Paraguay (Gray et al., 1992).

To the north, in the Parnaiba Basin of central-eastern Brazil, the Serra Grande Group rests unconformably above the Proterozoic basement or Cambro-Ordovician sandstones (Vaz et al., 2007). The lower Ipu Formation consists of conglomerates, cross-bedded sandstones, pebbly sandstones, and diamictites ranging in thickness from 6 to $20 \mathrm{~m}$, interpreted as reworked tillites deposited in glaciofluvial (outwash deposits) and fan-delta environments
(Caputo and Crowell, 1985; Grahn and Caputo, 1992). This unit is overlain by, and interfinger with, the Tianguá Formation, which comprises dark-gray ferruginous shales and bioturbated micaceous siltstones and sandstones representing shallow marine deposits (Góes and Feijó, 1984) generated during the postglacial transgression. Palynomorphs indicates that the Tianguá shales are Early Silurian in age (Caputo and Lima, 1984; Grahn et al., 2005), and therefore, a Late Ordovician age can be inferred for the underlying diamictite (Vaz et al., 2007).

\section{Discussion}

The correlation between the successions summarized above is possible due to the recognition of three main stratigraphic markers. The first marker is the sequence boundary surface (SBS) generated during the glacioeustatic sea-level fall, the second marker is the extensive flooding surface related to postglacial melting, and the third one is the development of ferruginous deposits, which are genetically related with the transgressive event (Figs. 6 and 7).

The sea-level fall during the maximum extent of the Gondwana ice sheet in the Hirnantian was estimated over $100 \mathrm{~m}$ by Loi et al. (2010). In the South American basins it is reflected by widespread valley incision. Paleovalley infill initiates with cross-stratified sandstones and lenticular clast-supported conglomerates of fluvial origin including lithologies representative from different underlying strata. This reveals an extensive erosional phase, which represents a SBS. The drowning of fluvial systems during the early transgressive systems tract led to the accumulation of fluvioestuarine deposits, which are better developed where the SBS rests on Ordovician folded rocks, as in W Puna region, or on the Proterozoic basement, as in the Paraguayan and Brazilian sectors of the Paraná Basin. On the contrary, in those areas flooded by the sea during the Late Ordovician, the abrupt sea-level fall is expressed by a sharp contact of glacial diamictites over shallow to open marine deposits of Sandbian to early Katian age (Precordillera, Subandean Ranges, Cordillera Oriental), and the SBS takes the form of a subaerial to subglacial unconformity. In southern Bolivia, the sequence starts with brecciated and internally deformed sandstones indicating glacial abrasion and subglacial soft deformation of the underlying Lower Ordovician strata (Schönian and Egenhoff, 2007). The precise age of the early phase of the transgressive systems tract is difficult to constrain because the estuarine strata only contain trace fossils lacking chronologic value (e.g. Skolithos, Cruziana).

The estimated magnitude of the post-Hirnantian glacioeustatic sea-level rise ranges from 45 to $80 \mathrm{~m}$ supporting the existence of a North African ice sheet and separate ice masses located on the Central Andes and South Africa (Le Heron and Dowdeswell, 2009). As a consequence, marine deposits onlap onto the paleovalley margins and covered the vast intracratonic areas emerged since the end of the Proterozoic. Overall, onlap geometry of the transgressive surface and succeeding marine deposits become evident from the correlation of the surveyed stratigraphic sections (Figs. 6 and 7). According to the palentological evidence, basinward flooding took place essentially in the Hirnantian ( $N$. persculptus Biozone) or during the Hirnantian/Rhuddanian transition. In most northern Gondwana basins (North Africa, Arabia) the post-glacial transgressive deposits are represented by black shales ('hot shales'), which form a marker horizon at the base of the Silurian. It has been argued that such organic-rich shales resulted from high productivity, eutrophy of epeiric seas, and dysoxic/anoxic bottom conditions (Page et al., 2007; Cherns and Wheeley, 2009). Age-equivalent deglacial black shales are also known in the Cape Basin of South Africa (Soom Shale), which overlie glacial diamictites (Pakhuis Formation) deposited in subaerial, fluvioglacial and marinemarginal environments (Young et al., 2004) (Fig. 7). It should be 
noted that Van Staden et al. (2010), on the basis of sedimentological and detrital-zircon geochronological evidence, correlated the Pakhuis diamictite with the Sierra del Volcán diamictite of the Tandilia System, formerly considered of Proterozoic age, demonstrating the continuity of the Hirnantian ice sheet trough South-Africa and eastern Argentina (Fig. 8).

In southern South America, biostratigraphic evidence strongly suggests that the rapid glacioeustatic sea level rise was associated to low sedimentation rates leading to condensed deposits and/or omission surfaces. A good example is the Talacasto section in the Precordillera Basin where three biozones ( $N$. persculptus, $P$. acuminatus, and $A$. atavus) occur consecutively within the lowermost $1.60 \mathrm{~m}$ of the La Chilca Formation (Cuerda et al., 1988). In the Zapla Range, the transgressive basal conglomerate that overlies the glacial diamictite is succeeded by a 5 -m thick condensed succession of bioturbated shales and ferruginous beds containing Rhuddanian, Aeronian and Telychian chitinozoans (de la Puente et al., 2012). In the Cordillera Oriental of NW Argentina the palynological and graptolite evidence from the transgressive shales indicates a Llandovery (probably late Aeronian) age (Rubinstein and Toro, 2006); therefore, it can be inferred that between the basal ferruginous sandstones and the overlying open shelf shales there is a gap involving the Rhuddanian and part of the Aeronian. In Paraguay, biostratigraphic data also indicate a low rate of sedimentation at the contact between the upper Hirnantian/lower Rhuddanian ferruginous sandstones of the top of the Eusebio Ayala Formation and the overlying Aeronian/lower Telychian open marine shales of the Vargas Peña Formation. A similar gap could be present in the Brazilian sector of the Paraná Basin between the ferruginous sandstones deposited at the top of the Iapó diamictite and the Vila María shales.

The link of ironstones with episodes of widespread transgression and low clastic influx has been underlined by many workers (Van Houten,1985; Van Houten and Bhattacharyya, 1982; Young, 1989). Stratigraphic evidence from the analyzed South American basins indicates that most iron-rich deposits formed during the early stages of the extensive postglacial transgression around the Ordovician/Silurian transition (Figs. 6 and 7). It seems likely that the mild maritime climate leading to melting of the Gondwana ice sheet together with increasing atmospheric $\mathrm{CO}_{2}$ were responsible for weathering of the widespread sediments produced by glacial action. Their reworking during the transgressive event supplied iron to the marine system enough to generate the ferruginous allochems (Young, 1989). Although highlatitude Ordovician ironstones are thought to have been generated without the action of land plants (Van Houten, 1985), the finding of terrestrial plant megaspores in Middle Ordovician (Dapingian) rocks of the Zapla Range (Rubinstein et al., 2010) and of trilete spores indicating the advent of vascular plants in the region by the Hirnantian (Rubinstein et al., 2015) allow infer the existence of incipient vegetated areas enhancing chemical weathering around the Ordovician/Silurian boundary.

\section{Conclusions}

Taphonomic and paleoecologic evidence indicate that the shelly fauna recovered from the top of the Zapla Formation in the Subandean Ranges of NW Argentina was not transported and represents at least partially the original community. The assemblage of brachiopods, bivalves, and trilobites is closely comparable to the widespread latest Ordovician Hirnantia-Dalmanitina fauna. The Hirnantian age of the Zapla diamictite is further corroborated by the recent discovery of the northern Gondwana chitinozoans including Spinachitina cf. oulebsiri and Desmochitina minor typica. Equivalent glacial levels of the Caspalá Formation contain late
Katian chitinozoans interpreted as a recycled association during the Hirnantian glacial events. This age is also consistent with the lowest Llandovery ( $P$. acuminatus Biozone) graptolites and chitinozoans recovered from the base of overlying Lipeón Formation. The postglacial transgression has been dated as Rhuddanian to Aeronian in most of the South American basin. It was associated with low sedimentation rates and widespread formation of iron-rich strata. The mild maritime postglacial climate, the increasing atmospheric $\mathrm{CO}_{2}$, and possibly the presence of incipient vegetated land areas led to extensive weathering of the large amount of glacigenic sediments supplying iron into the marine system to form the ferruginous deposits.

To account for the younger Lower Silurian age of the diamictite exposed north of La Paz in Bolivia and southern Peru we postulate that palynomorphs are dating the resedimentation of the striated and faceted boulders into the deep basin and not the autochthonous glacial deposits. In our interpretation, the ablation of glaciers led to a rapid and widespread accumulation of glacial sediments, which were reworked and redistributed by high-energy marine processes along the shore during the postglacial transgression, and then partly incorporated into gravity flows. The great thickness of olistostromic successions, the coexistence of striated and faceted boulders with large olistoliths, and the interbedded turbiditic deposits support accumulation in a tectonically active deep-marine trough.

Evidence from lithofacies and stratigraphic markers, in particular the ubiquitous ironstone beds and the postglacial transgressive surface, have been used to adjust the correlation of the Subandean Ranges successions with other basins. In long-standing emergent areas (e.g. Paraná Basin, W Puna basin) the glacial event is recorded by incision of paleovalleys during the sea level fall, but in those areas flooded by the sea during the Sandbian/Katian the lower contact of glacial deposits is an erosional surface truncating preglacial strata. A sharp surface at the base of transgressive postglacial deposits is traceable over the whole intracratronic and preAndean basins of southern South America.

\section{Acknowledgments}

JLB and $\mathrm{KH}$ wish to acknowledge the assistance of the Consejo Nacional de Investigaciones Científicas y Técnicas (CONICET) and the Universidad Nacional de Córdoba, both of which support facilities used in this investigation. Financial support for this study was provided by FONCYT (PICT 2010-2784 and PICT 2013-2206) and CONICET (PIP 11220120100364). We also would like to thank D.A.T. Harper who critically reviewed the manuscript and greatly helped to improve it. Thanks to Glenn Schlereth for advising with some language issues.

\section{References}

Alfaro, M.B. Uriz, N.J, Cingolani, C.A., Tortello, F. Bidone, A.R. Galeano Inchausti, J.C., 2012. Normalograptus persculptus Biozone record (graptolites and trilobites) in the Eusebio Ayala Formation: new Hirnantian-Llandovery sequence within the Paraná Basin in Eastern Paraguay. Geol. J. 48 (2-3), $236-247$.

Amstrong, H.A., 2007. On the cause of the Ordovician glaciation. In: Williams, M., Haywood, A.M., Gregory, F.J., Schmidt, D.N. (Eds.), Deep-time Perspectives on Climate Change. Marrying the Signal from Computer Models and Biological Proxies. The Micropaleontological Society Special Publications, Geological Society of London, pp. 101-122.

Anaya, F., Pacheco, J., Pérez, H., 1987. Estudio estratigráfico paleontológico de la Formación Cancañiri en la Cordillera del Tunari (Departamento de Cochabamba). In: Suárez Riglos, M., Suárez Soruco, R. (Eds.), Memorias $4^{\circ}$ Congreso Latinoamericano de Paleontología, Santa Cruz de la Sierra, 2, pp. 679-693.

Antelo, B., 1973. La fauna de la Formación Cancañiri (Silúrico) en los Andes Centrales Bolivianos. Revista del Museo de La Plata (nueva serie). Sección Paleontol. 45 267-277.

Assine, M.L., Soares, P.C., Milani, E.J., 1994. Seqüencias tectono-sedimentares 
mesopaleozóicas da Bacia do Paraná. Rev. Bras. Geociencias 24, 77-89.

Astini, R.A., 1992. Descripción y génesis de los bancos de oolitas ferruginosas en la base del Silúrico de la Precordillera Argentina. Estud. Geol. 48, 297-303.

Astini, R.A., 1999. The Late Ordovician glaciation in the Proto-Andean margin of Gondwana revisited: geodynamic implications. In: Kraft, P., Fatka, O. (Eds.), Quo Vadis Ordovician? Acta Universitatis Carolinae, Geologica, 43 (1-2), pp. 171-174.

Astini, R.A., 2001. Pavimentos estriados en la Formación Don Braulio y naturaleza de la glaciación hirnantiana (Ordovícico Tardío) en la región Andina. Rev. la Asoc. Argent. Sedimentol. 8, 1-25.

Astini, R.A., 2003. The ordovician proto-Andean basins. In: Benedetto, J.L. (Ed.), Ordovician Fossils of Argentina. Secretaría de Ciencia y Tecnología, Universidad Nacional de Córdoba, Córdoba, pp. 1-74.

Astini, R.A., Benedetto, J.L., 1992. El Ashgilliano tardío (Hirnantiano) del Cerro La Chilca, Precordillera de San Juan. Ameghiniana 29, 249-264.

Astini, R.A., Benedetto, J.L., Vaccari, N.E., 1995. The Early Paleozoic evolution of the Argentine Precordillera as a rifted, drifted and collided terrane: a geodynamic model. Geol. Soc. Am. Bull. 107, 253-273.

Astini, R.A., Toro, B.A., Waisfeld, B.G., Benedetto, J.L., 2004. Revisión estratigráfica de la región de Los Colorados: Un perfil condensado del Paleozoico inferior en el borde occidental del Cordillera Oriental, Provincia de Jujuy. Rev. la Asoc. Geol. Argent. 59, 243-260.

Baldis, B.A., Blasco, G., 1975. In: Primeros trilobites ashgillianos del Ordovícico sudamericano. Actas $1^{\circ}$ Congreso Argentino de Paleontología y Bioestratigrafía, S. M. de Tucumán, 1, pp. 33-48.

Bassett, M.G., 1984. Life strategies of Silurian brachiopods. In: Bassett, M.G., Lawson, J.D. (Eds.), Autecology of Silurian Organisms. Special Papers in Palaeontology, 32, pp. 237-264.

Benedetto, J.L., 1986. The first typical hirnantia fauna from south america (San Juan province, argentine precordillera). In: Racheboeuf, P.R., Emig, D. (Eds.), Les, Brachiopodes fossiles et actuels. Biostratigraphie du Paleozoïque, 4, pp. $439-477$.

Benedetto, J.L., 1990. Los géneros Cliftonia y Paromalomena (Brachiopoda) en el Ashgilliano tardío de la Sierra de Villicum, Precordillera de San Juan. Ameghiniana 27, 151-159.

Benedetto, J.L., 1991. Braquiópodos silúricos de la Formación Lipeón, flanco occidental de la Sierra de Zapla, Provincia de Jujuy, Argentina. Ameghiniana 28, $111-125$.

Benedetto, J.L., 1995. Braquiópodos del Silúrico temprano (Llandoveriano) Malvinocáfrico, Formación La Chilca, Precordillera Argentina. Geobios 28, 425-457.

Benedetto, J.L., 2004. The allochthony of the Precordillera ten years later (19932003): a new paleobiogeographic test of the microcontinental model. Gondwana Res. 7, 1027-1039.

Benedetto, J.L., 2013. Upper Ordovician brachiopods from the San Benito Formation, Cordillera del Tunari, Bolivia. Ameghiniana 50, 418-428.

Benedetto, J.L., Cocks, L.R.M., 2009. Early Silurian (Rhuddanian) brachiopods from the Argentine Precordillera and their biogeographic affinities. Ameghiniana 46, $241-253$.

Benedetto, J.L., Montoya, E., 2015. The Afro-South American brachiopod Castellaroina Boucot from the Silurian of the Argentine Precordillera: its origin and phylogenetic relationships. Palaöntologische Z. 89, 1-24.

Benedetto, J.L., Sánchez, T.M., 1990. Fauna y edad del estratotipo de la Formación Salar del Rincón (Eopaleozoico, Puna Argentina). Ameghiniana 27, 317-326.

Benedetto, J.L., Suárez Soruco, R., 1998. In: Los braquiópodos del Silúrico de la Cordillera del Tunari (Cochabamba, Bolivia) y su correlación con otras sucesiones sedimentarias gondwánicas. Memorias $13^{\circ}$ Congreso Geológico Boliviano, Potosí, 1, pp. 153-159.

Benedetto, J.L., Toro, B.A., 1996. In: Hallazgo de braquiópodos del Ordovícico Tardío y Silúrico en la Cordillera Oriental de Jujuy, Argentina. Reunión Anual de Comunicaciones Asociación Paleontológica Argentina. Ameghiniana, 33, p. 228.

Benedetto, J.L., Sánchez, T.M., Brussa, E.D., 1992. Las cuencas Silúricas de América Latina. In: Gutiérrez-Marco, J.C., Saavedra, J., Rábano, I. (Eds.), Paleozoico inferior de Ibero-América. Universidad de Extremadura, pp. 119-148.

Benedetto, J.L., Sánchez, T.M., Halpern, K., Carrera, M.G., Bertero, V., 2011. Faunal shifts and climatic changes in the Upper Ordovician of South America (W Gondwana). In: Gutiérrez Marco, J.C., Rábano, I., García Bellido, D. (Eds.), Ordovician of the World. Cuadernos del Museo Geominero, Madrid, 14, pp. 55-60.

Benedetto, J.L., Halpern, K., Galeano Inchausti, J.C., 2013. High-latitude hirnantian (latest ordovician) brachiopods from the eusebio ayala formation of Paraguay, paraná Basin. Palaentology 56, 61-78.

Berry, W.B.N., Boucot, A.J. (Eds.), 1972. Correlation of the South American Silurian Rocks. The Geological Society of America Special Paper, 133, pp. 1-59.

Berry, W.B.N., Boucot, A.J., 1973. Glacio-eustatic control of Late Ordovician-Early Silurian platform sedimentation and faunal changes. Geol. Soc. Am. Bull. 84, 275-284.

Bosio, M.G., 2000. Estratigrafía y correlación bioestratigráfica de la Formación La Chilca (Silúrico Temprano) de la Precordillera de San Juan, Argentina. Universidad Nacional de Córdoba, Facultad de Ciencias Exactas, Físicas y Naturales, p. 125 (Trabajo Final, Córdoba).

Boso, M.A., 1996. Los ambientes sedimentarios de la Formación Zapla en el noroeste argentino. In: Memorias $12^{\circ}$ Congreso Geológico Boliviano, Tarija, pp. 951-960.

Boso, M.A., Monaldi, C.R., 2008. Cuenca Silúrico-Devónica y los depósitos ferríferos asociados en la Provincia de Jujuy. In: Relatorio $17^{\circ}$ Congreso Geológico Argentino, San Salvador de Jujuy, 166-165.
Boucot, A.J., Gonçalves de Melo, J.H., Santos Neto, E.V., Wolff, S., 1991. First clarkeia and heterorthella (Brachiopoda; lower silurian) occurrence from the paraná Basin in eastern Paraguay. J. Paleontol. 65, 512-514.

Brand, U., Azmy, K., Veizer, J., 2006. Evaluation of the Salinic I tectonic, Cancañiri glacial and Ireviken events: Biochemostratigraphy of the Lower Silurian succession in the Niagara Gorge area, Canada and U.S.A. Palaeogeogr. Palaeoclimatol. Palaeoecol. 241, 192-213.

Brenchley, P.J., Cocks, L.R.M., 1982. Ecological associations in a regressive sequence: the latest Ordovician of the Oslo-Asker District. Palaeontology 25, 783-815.

Brockmann, C., Castaños, A., Suárez Soruco, R., Tomasi, P., 1972. Estudio geológico de la Cordillera Oriental de los Andes en la zona central de Bolivia (Región de Chapare). Bol. la Soc. Geol. Boliv. 18, 3-36.

Buggisch, W., Astini, R.A., 1993. The late ordovician ice age: new evidence from the argentine precordillera. In: Findlay, R.H., Unrug, R.M., Banks, R., Veevers, J.J. (Eds.), Gondwana Eight. Assembly, Evolution and Dispersal, Hobart, Tasmania pp. $439-447$.

Caputo, M.U., Crowell, J.C., 1985. Migration of glacial centers across Gondwana during Paleozoic Era. Geol. Soc. Am. Bull. 96, 1020-1036.

Caputo, M.U., Lima, E.C., 1984. In: Estratigrafia, idade e correlação do Grupo Serra Grande. Anales $33^{\circ}$ Congresso Brasileiro de Geologia, Rio de Janeiro, 2, pp. 740-753.

Carrera, M.G., Halpern, K., 2011. A posglacial bryozoan fauna from the Upper Ordovician (Hirnantian) of the Argentine Precordillera. In: Gutiérrez Marco, J.C. Rábano, I., García Bellido, D. (Eds.), Ordovician of the World, 14. Cuadernos del Museo Geominero, Madrid, pp. 89-94.

Cherns, L., Wheeley, J.R., 2009. Early Palaeozoic cooling events: peri-Gondwana and beyond. In: Basset, M.G. (Ed.), Early Palaeozoic Peri-gondwana Terranes: New Insights from Tectonic and Biogeography. Geological Society London, Special Publications, 325, pp. 257-278.

Cingolani, C.A., Uriz, N.J., Alfaro, M.B., Tortello, F., Bidone, A.R., Galeano Inchausti, J.C., 2011. The Hirnantian-early Llandovery transition sequence in the Paraná Basin, eastern Paraguay. In: Gutiérrez-Marco, J.C., Rábano, I., García Bellido, D. (Eds.), Ordovician of the World, 14. Cuadernos del Museo Geominero, Madrid, pp. 103-108.

Cocks, L.R.M., 1972. The origin of Silurian Clarkeia shelly fauna of South America, and its extension to west Africa. Palaeontology 15, 623-630.

Cocks, L.R.M., Fortey, R.A., 1986. New evidence on the South African Lower Palaeozoic: age and fossils reviewed. Geol. Mag. 123, 437-444.

Crowell, J.V., Suárez Soruco, R., Rocha Campos, A.C., 1981. The silurian cancañiri formation (Zapla) formation of Bolivia, Argentina, and Peru. In: Hambrey, M.J., Harland, W.D. (Eds.), Earth's Pre-Pleistocene Glacial Record. Cambridge University Press, Cambridge, pp. 902-907.

Cuerda, A., Rickards, R.B., Cingonalni, C., 1988. A new Ordovician-Silurian boundary section in San Juan Province, Argentina, and its definitive graptolite fauna. Jopurnal Geol. Soc. Lond. 145, 749-757.

Dahlqvist, P., Harper, D.A.T., Wickström, L., 2010. Late Ordovician shelly faunas from Jämtland: palaeocommunity development along the margin of the Swedish Caledonides. Bull. Geosci. 85, 505-512.

Dalman, J.W., 1828. Upställning och Beskrifning af de i Sverige funne Terebratuliter. Kongliga Vewtenskasakademien Handlingar för Ấr 1827, pp. 85-155.

de la Puente, G.S., 2014. Chitinozoans throughout the Ordovician/Silurian boundary in northwestern Argentina, western Gondwana. In: $4^{\text {th }}$. International Palaeontological Congress, Mendoza, Abstracts, 915.

de la Puente, G.S., Rubinstein, C.V., 2013. Ordovician chitinozoans and marine phytoplankton of the Central Andean Basin, northwestern Argentina: a biostratigraphic and paleobiogeographic approach. Rev. Palaeobot. Palynol. 198, 14-26.

de la Puente, G.S., Astini, R.A., Rubinstein, C.V., Oviedo, N., 2012. Latest Ordovicianearliest silurian chitinozoans from northwestern Argentina, western gondwana. In: 45th Annual Meeting of AASP - The Palynological Society and Meeting of the CIMP - Commission Internationale de la Microflore du Paléozoïque Subcommissions, Program and Abstracts, Lexington, pp. 17-19.

de la Puente, G.S., Rubinstein, C.V., Vaccari, N.E., Paris, F., 2015. Latest Ordovicianearliest silurian chitinozoans from puna, western gondwana. In: Leslie, S.A., Goldman, D., Ordorff, R.C. (Eds.), 12th. International Symposium on the Ordovician System, Short Papers and Abstracts, Stratigraphy, 12 (2), pp. 127-128.

Desrochers, A., Farley, C., Achab, A., Asselin, E., Riva, J.F., 2010. A far-field record of the end ordovician glaciation: the Ellis Bay formation, Anticosti island, eastern Canada. Palaeogeogr. Palaeoclimatol. Palaeoecol. 296, 248-263.

Díaz-Martínez, E., 2007. The Sacta Limestone Member (early Wenlock): cool-water, temperate carbonate deposition at the distal foreland of Gondwana's active margin, Bolivia. Palaeogeogr. Palaeoclimatol. Palaeoecol. 245, 46-61.

Díaz-Martínez, E., Grahn, Y., 2007. Early Silurian glaciation along the western margin of Gondwana (Perú, Bolivia and northern Argentina). Palaeogeogr. Palaeoclimatol. Palaeoecol. 245, 62-81.

Díaz-Martínez, E., Limachi, R., Goitía, V.H., Sarmiento, D., Arispe, O., Montecinos, R. 1996. Tectonic instability related with the development of the Paleozoic foreland basin of the Central Andes of Bolivia. In: Abstracts 3rd. International Symposium on Andean Geodynamics, St. Malo, pp. 343-346.

Díaz-Martínez, E., Acosta, H., Cárdenas, J., Carlotto, V., Rodríguez, R., 2001. Palaeozoic duiamictites in the Peruvian Altiplano: evidence and tectonic implications. J. S. Am. Earth Sci. 14, 587-592.

Díaz-Martínez, E., Vavrdová, M., Isaacson, P.E., Grahn, C.Y., 2011. Early silurian vs. Late ordovician glaciation in South America. In: Gutiérrez-Marco, J.C., Rábano, I., García-Bellido, D. (Eds.), Ordovician of the World, 14. Cuadernos del Museo 
Geominero, Madrid, pp. 127-134.

Donato, E.O., Vergani, G., 1985. Geología del Devónico y Neopaleozoico de la zona del Cerro Rincón, Provincia de Salta, Argentina. In: Actas 4 Congreso Geológico Chileno, Antofagasta, 1, pp. 262-283.

Egenhoff, S.O., 2003. Review of Ordovician basin evolution in southern Bolivia. In: Albanesi, G.L., Beresi, M.S., Peralta, S.H. (Eds.), Ordovician from the Andes. INSUGEO Serie Correlación Geológica, S. M. de Tucumán, 17, pp. 409-412.

Egenhoff, S.O., Lucassen, F., 2003. Chemical and isotopic composition of Lower and Upper Ordovician sedimentary rocks (Central Andes of Bolivia): implications for their source. J. Geol. 111, 487-497.

Egenhoff, S.O., Maletz, J., Erdtmann, B.D., 1999. Upper Ordovician basin evolution in southern Bolivia. In: Kraft, P., Fatka, O. (Eds.), Quo vadis Ordovician, 43 (1-2) Acta Universitatis Carolinae, Geologica, pp. 127-130.

Erdtmann, B.D., Suárez Soruco, R., 1999. The ordovician tectonostratigraphy of Bolivia. In: Kraft, P., Fatka, O. (Eds.), Quo vadis Ordovician, 43 (1-2). Acta Universitatis Carolinae, Geologica, pp. 175-178.

Eyles, M., 2008. Glacio-epochs and the supercontinent cycle after $3.0 \mathrm{Ga}$ : tectonic boundary conditions for glaciation. Palaeogeogr. Palaeoclimatol. Palaeoecol 258, 89-129.

Figueredo, L., 1995. Descripción geológica del pozo RD 116 Santa Elena-Paraguay. In: González Núñez, M., Lahner, L., Cubas, N., Adelaida, D. (Eds.), Mapa Geológico de la República del Paraguay, Hoja Coronel Oviedo 5670 1:100.000. Cooperación Técnica BGR-MOPC, Asunción.

Finnegan, S., Bergmann, K., Eiler, J.M., Jones, D.S., Fike, D.A., Eisenman, I., Hughes, N.C., Tripati, A.K., Fisher, W.W., 2011. The magnitude and duration of Late Ordovician-Early Silurian glaciation. Science 331, 903-906.

Forshite, R.D., Davidson, J., Mpodozis, C., 1993. Lower Paleozoic relative motion of the Arequipa block and Gondwana: paleomagnetic evidence from Sierra de Almeida of northern Chile. Tectonics 12, 219-236.

Gagnier, P.Y., Blieck, A., Emig, C.C., Sempere, T., Vachard, D., Vanguestaine, M., 1996. New paleontological and geological data on the Ordovician and Silurian of Bolivia. J. S. Am. Earth Sci. 9, 329-347.

Góes, A.M.O., Feijó, F.J., 1984. Bacia do Parnaíba. Bol. Geociências Petrobras 8, 57-68.

González, M., Díaz-Martínez, E., Ticlla, L., 1996. Comentarios sobre la estratigrafía del Silúrico y Devónico del norte y centro de la Cordillera Oriental y Altiplano de Bolivia. In: Pilatti, F. (Ed.), Anais do Simpósio Sul Americano do Silurodevoniano, Ponta Grossa, pp. 117-130.

Gosen, W. von, Buggisch, W., Lehnert, O., 1995. Evolution of the Early Paleozoic mélange at the eastern margin of the Argentine Precordillera. J. S. Am. Earth Sci. 8, 405-424.

Grahn, Y., Caputo, M.V., 1992. Early silurian glaciations in Brazil. Palaeogeogr Palaeoclimatol. Palaeoecol. 99, 9-15.

Grahn, Y., Gutiérrez, P.R., 2001. Silurian and middle devonian Chitinozoa from the zapla and santa bárbara ranges, tarija Basin, northwestern Argentina. Ameghiniana 38, 35-50.

Grahn, Y., Melo, J.H.G., Steemans, P., 2005. Integrated chitinozoan and miospore zonation of the Serra grande group (Silurian-Lower Devonian), Parnaíba Basin, Northeast Brazil. Rev. Española Micropaleontol. 37, 183-204.

Gray, J.E., 1840. Synopsis of the contents of the British Museum, 42nd ed. British Museum, London, p. 370

Gray, J., Colbarth, G.K., Faría, A., Boucot, A.J., Rohr, D.M., 1985. Silurian age fossils from the Paleozoic Paraná Basin, southern Brazil. Geology 13, 521-525.

Gray, J., Boucor, A.J., Grahn, Y., Himes, G., 1992. A new record of early Silurian land plant spores from the Paraná Basin, Paraguay (Malvinokaffric Realm). Geol. Mag. 129, 741-752.

Halpern, K., Carrera, M.G., 2014. Post-glacial Hirnantian (Upper Ordovician) bryozoans from western Argentina: implications for survival and extinction patterns. Ameghiniana 51, 243-253.

Halpern, K., Rustán, J.J., Meroi Acerito, F.R., 2014. The first Hirnantian (uppermost Ordovician) odontopleurid trilobite from western Gondwana (Argentina). Rev. Bras. Paleontol. 17, 3-9.

Harper, D.A.T. Williams, S.H., 2002. A relict Ordovician brachiopod fauna from the Parakidograptus acuminatus Biozone (Lower Silurian) of the English Lake District. Lethaia 35, 71-78.

Harrington, H.J., 1950. In: Geología del Paraguay Oriental. Facultad de Ciencias Exactas, Contribuciones Científicas, Sección E (Geología), 1, pp. 1-82.

Harrington, H.J., 1972. Silurian of Paraguay. In: Berry, W.B.N., Boucot, A.J. (Eds.), Correlation of South American Silurian Rocks. Geological Society of America Special Papers, 133, pp. 41-50.

Heim, A., 1948. Observaciones tectónicas en La Rinconada, Precordillera de San Juan. Bol. la Dirección Minas Geol. 114, 1-85.

Hints, L., Pärnaste, H., Gailite, L.I., 2012. Hirnantia sagittifera (Brachiopoda) and Mucronaspis mucronata s.l. (Trilobita) in the Upper Ordovician of the East Baltic: taxonomy and distribution. Est. J. Earth Sci. 61, 65-81.

Isaacson, P.E., Antelo, B., Boucot, A.J., 1976. Implications of a llandovery (Early Silurian) brachiopod fauna from Salta province, Argentina. J. Paleontology 50 1103-1112.

Jin, J., Bersgrtröm, J., 2010. True Dalmanella and taxonomic implications for some Late Ordovician dalmanellid brachiopods from North America. GFF 132, 13-24.

Keidel, H., 1939. Über die "Gondwaniden" Argentiniens. Geol. Rundsch. 30, $148-249$

Kley, J., Monaldi, C.R., 1999. Estructura de las Sierras Subandinas y del Sistema de Santa Bárbara. In: González Bonorino, G., Omarini, R., Viramonte, J. (Eds.), 14 Congreso Geológico Argentino, Salta, Relatorio Geología del Noroeste Argentino, 1, pp. 415-425.
Kley, J., Monaldi, C.R., 2002. Tectonic inversion in the Santa Bárbara System of the Central Andean foreland thrust belt, northwestern Argentina. Tectonics 21, $1-18$.

Laubacher, G., Boucot, A.J., Gray, J., 1982. Additions to Silurian stratigraphy, lithofacies, biogeography and paleontology of Bolivia and southern Peru. J. Paleontol. 56, 1138-1170.

Le Heron, D.P., Dowdeswell, J.A., 2009. Calculating ice volumes and ice flux to constrain the dimensions of a 440 Ma North African ice sheet. J. Geol. Soc. Lond. $166,277-281$

Lehnert, O., Männik, P., Joachimki, M.M., Calner, M., Frýda, J., 2010. Palaeoclimante perturbations before the Sheinwoodian glaciations: a trigger for extinctions during the 'Ireviken Event'. Palaeogeogr. Palaeoclimatol. Palaeoecol. 296, 320-331.

Lespérance, P.J., 1974. The hirnantian fauna of the Percé area (Quebec) and the Ordovician-Silurian boundary. Am. J. Sci. 274, 10-30.

Levy, R., Nullo, F., 1974. La fauna del Ordovícico (Ashgilliano) de Villicun, San Juan, Argentina (Brachiopoda). Ameghiniana 9, 173-200.

Limachi, R., Goitia, V.H., Sarmiento, D., Arispe, O., Montecinos, R., Díaz Martínez, E., Dalenz Farjat, A., Liachenko, N., Pérez Leytón, M., Aguilera, E., 1996. In: Estratigrafía, geoquímica, correlaciones, ambientes sedimentarios y bioestratigrafía del Silúrico-Devónico de Bolivia. Memorias $12^{\circ}$ Congreso Geológico de Bolivia, 1 , pp. 183-197.

Lin, T., 1981. Songxites, a new subgenus of Dalmanitina (Trilobita) from the late Upper Ordovician of Jiangxi. Acta Palaeontol. Sin. 20, 88-91.

Lobo, J., Suárez Riglos, M., Suárez Soruco, R., 1976. Nuevas unidades cronoestratigráficas para el Paleozoico medio de la Provincia Austral Sudamericana. In: Actas $12^{\circ}$ Reunión Anual de Expertos ARPEL, Buenos Aires, pp. 1-15.

Loi, A., Ghienne, J.F., Dabard, M.P., Paris, F., Botquelen, A., Christ, N., ElaouadDebbaj, Z., Gorini, A., Vidal, M., Videt, B., Destombes, J., 2010. The Late Ordovician glacio-eustatic record from a high-latitude storm dominated shelf succession: the Bou Ingarf section (Anti-Atlas, southern Morocco). Palaeogeogr Palaeoclimatol. Palaeoecol. 296, 332-358.

Merino, D., 1991. Primer registro de conodontos silúricos en Bolivia. Rev. Técnica Yacimientos Pet. Fisc. Boliv. 12, 271-274.

Milani, E.J., Gonçalves de Melo, J.H., De Souza, P., Fernández, L.A., Barros França, A., 2007. Bacia do paraná. Bol. Gociencias Petrobras 15, 265-287.

Mizusaki, A.M., Melo, J.H.G., Vignoli-Lelarge, M.L., Steemans, P., 2002. Vila Maria formation (Silurian, paraná Basin, Brazil): integrated radiometric and palynological age determinations. Geol. Mag. 139, 453-463.

Monaldi, C.R., Boso, M.A., 1987. In: Dalmanitina (Dalmanitina) subandina nov. sp. (Trilobita) en la Formación Zapla del norte argentino. Actas $4^{\circ}$ Congreso Latinoamericano de Paleontología, Santa Cruz de la Sierra, 1, pp. 149-157.

Montaño, G.B., 1994. Estratigrafía del Río Sacta, Departamento de Cochabamba. Rev. Técnica YPFB 15, 33-46.

Monteros, J.A., Moya, M.C., Cuerda, A., 1993. In: Graptolitos ashgillianollandoverianos en la base de la Formación Lipeón, sierra de Zapla, Jujuy. Su importancia en la correlación con el Silúrico de la Precordillera argentina. Actas $12^{\circ}$ Congreso Geológico Argentino y $2^{\circ}$ Congreso de Exploración de Hidrocarburos, Mendoza, 2, pp. 304-314.

Moya, M.C., Monteros, J.A., 1999. In: El Ordovícico Tardío y el Silúrico en el borde occidental de la Cordillera Oriental argentina. Actas $14^{\circ}$ Congreso Geológico Argentino, Salta, 1, pp. 401-404.

Nyemeyer, H., Alvarez, F., Boucot, A.J., Bruna, M., 2010. Brachiopods from Cordón de Lila, Lower Silurian (Llandovery) Quebrada Ancha Formation, Antofagasta region, Chile. Palaeontology 84, 287-307.

Owen, A.W., 1981. The trilobite Mucronaspis in the uppermost Ordovician of the Oslo Region, Norway. Norsk Geologisk Tidsskrift 61, 271-279.

Owen, A.W., 1986. The uppermost Ordovician (Hirnantian) trilobites of Girvan, SW Scotland with a review of coeval trilobite faunas. Tran. Royal Soc. Edinburgh Earth Sci 77, 231-239.

Owen, A.W., Harper, D.A.T., Rong, J.Y., 1991. Hirnantian trilobites and brachiopods in space and time. In: Barnes, Ch. Williams, S.H. (Eds.), Advances in Ordovician Geology, 90. Geological Survey of Canada, Paper, pp. 179-190.

Page, A., Zalasiewicz, J., Williams, M., Popov, L., 2007. Were transgressive black shales a negative feedback modulating glacioeustasy in the Early Palaeozoic Icehouse? In: Williams, M., Haywood, A.M., Gregory, FJ. (Eds.), Deep-time Perspectives on Climate Change: Marrying the Signal from Computer Models and Biological Proxies, 2. Micropalaeontological Society Special Publications, pp. 67-101.

Paris, F., Verniers, J., Miller, M.A., Al-Hajri, S., Melvin, J., Wellman, C.H., 2015. Late Ordovician-earliest Silurian chitinozoans from the Qusaiba-1 core hole (North Central Saudi Arabia) and their relation to the Hirnantian glaciation. Rev. Palaeobot. Palynol. 212, 60-84.

Peralta, S.H., 1985. Graptolites del Llandoveriano inferior en el Paleozoico clástico del pie oriental de la Sierra de Villicum. In: Primeras Jornadas sobre Geología de la Precordillera, San Juan, pp. 134-138.

Peralta, S.H., 2007. The Extensional History of the Devonian Basin of Precordillera: its Tectosedimentary Significance in the Evolution of the Cuyania Terrane. Devonian Land-Sea Interaction: Evolution of ecosystems and climate (DEVEC), pp. 102-105.

Peralta, S.H., Baldis, B.A., 1990. Glyptograptus persculptus en la Formación Don Braulio (Ashgilliano tardío-Llandoveriano temprano), Precordillera Oriental de San Juan, Argentina. In: Actas $5^{\circ}$ Congreso Argentino de Paleontología y Bioestratigrafía, San Juan, pp. 67-72.

Peralta, S.H., Carter, C., 1990. La glaciación gondwánica del Ordovícico tardío: 
evidencias en fangolitas guijarrosas de la Precordillera de San Juan. In: Actas $11^{\circ}$ Congreso Geológico Argentino, San Juan, 2, pp. 181-185.

Peralta, S.H., Uliarte, E.R., Lanzilotta, I., 1986. Estudio de los depósitos sedimentarios ferruginosos del Silúrico de la Precordillera de San Juan. In: Primeras Jornadas sobre Geología de la Precordillera, San Juan, pp. 301-306.

Pothe de Baldis, E.D., 1997. Acritarcas del Llandoveriano temprano-medio de la Formación Don Braulio, Precordillera Oriental, Provincia de San Juan, Argentina. Rev. Española Micropaleontol. 29, 31-68.

Ramos, V.A., 2008. The basement of the Central Andes: the Arequipa and related terranes. Annu. Rev. Earth Planet. Sci. 36, 289-324.

Ramos, V.A., Jordan, T.E., Allmendinger, R.W., Mpodozis, C., Kay, S.M., Cortés, J.M., Palma, M., 1986. Paleozoic terranes of the Central Argentine-Chilean Andes. Tectonics 5, 855-880.

Rickards, R.B., Brussa, E.D., Toro, B.A., Ortega, G., 1996. Ordovician and Silurian graptolite assemblages from Cerro del Fuerte, San Juan Province, Argentina. Geol. J. 31, 101-122.

Rickards, R.B., Ortega, G., Bassett, M., Boso, M.A., Monaldi, C.R., 2002. Talacastograptus, an unusual biserial graptolite, and other Silurian forms from Argentina and Bolivia. Ameghiniana 39, 343-350.

Rodrigo, L.A., Castaños, A., Carrasco, R., 1977. La Formación Cancañiri: sedimentología y paleogeografía. Rev. Geociencias la Univ. Mayor San Andrés 1, $1-22$.

Rolleri, E.O., 1976. In: El Sistema de Santa Bárbara. Actas 4 Congreso Geológico Argentino, 1, pp. 239-255.

Rong, J.Y., 1984. Brachiopods of latest Ordovician in the Yichang District, western Hubei, central China. In: Stratigraphy and Palaeontology of Systemic Boundaries in China, Ordovician-silurian Boundary, 1. Academia Sinica, Nanjing Institute of Geology and Palaeontology, Nanjing, pp. 111-176.

Rong, J.Y., Harper, D.A.T., 1988. A global synthesis of the latest Ordovician Hirnantian brachiopod faunas. Trans. R. Soc. Edinb. Earth Sci. 79, 383-402.

Rong, J.Y., Zhan, R.B., 2006. Surviving the end-Ordovician extinctions: evidence from the earliest Silurian brachiopods of northeastern Jiangxi and western Zhejiang provinces, East China. Lethaia 39, 39-48.

Rong, J.Y., Chen, X., Harper, D.A.T., 2002. The latest Ordovician Hirnantia Fauna (Brachiopoda) in time and space. Lethaia 35, 231-249.

Rubinstein, C.V., de la Puente, G.S., 2008. Bioestratigrafía del Paleozoico Inferior en las Sierras Subandinas, provincia de Jujuy. In: Coira, B., Zappettini, E.O. (Eds.), $17^{\circ}$ Congreso Geológico Argentino, Jujuy, Relatorio Geología y Recursos Naturales de Jujuy, pp. 128-133.

Rubinstein, C.V., Toro, B.A., 2006. Aeronian (Llandovery, lower silurian) palynomorphs and graptolites from the lipeón formation, eastern Cordillera, northwest Argentina. Geobios 39, 103-111.

Rubinstein, C.V., Vaccari, N.E., 2004. Cryptospore assemblages from the Ordovician/ Silurian boundary in the Puna region, North-West Argentina. Palaentology 47, 1037-1061.

Rubinstein, C.V., Gerrienne, P., de la Puente, G.S., Astini, R.A., Steemans, P., 2010. Early Middle Ordovician evidence for land plants in Argentina (eastern Gondwana). New Phytol. 188, 306-309.

Rubinstein, C.V., de la Puente, G.S., Delabroye, A., Astini, R.A., 2015. The palynological record across the Ordovician/Silurian boundary in the Cordillera Oriental, Central Andean Basin, northwestern Argentina. Rev. Palaeobot. Palynol. http://dx.doi.org/10.1016/j.revpalbo.2015.06.011.

Sánchez, T.M., 1989. Bivalvos paleotaxodóntidos de la Formación Lipeón (Silúrico) del noroeste argentino. Ameghiniana 26, 173-189.

Sánchez, T.M., 1990. Bivalvos del Ordovícico medio-tardío de la Precordillera de San Juan (Argentina). Ameghiniana 27, 251-261.

Sánchez, T.M., 1991. El género Dualina (Bivalvia, Praecardioida) en la Formación Lipeón (Silúrico), sierra de Zapla, provincia de Jujuy, Argentina. Ameghiniana $28,31-34$.

Sánchez, T.M., Astini, R.A., 2011. A new species of the Gondwanan genus Cardiolaria Munier-Chalmas in the Sandbianof northwestern Argentina: paleobiogeographic considerations. J. S. Am. Earth Sci. 31, 306-311.

Sánchez, T.M., Benedetto, J.L., Brussa, E.D., 1991. Late Ordovician stratigraphy, paleoecology and sea level changes in the Argentine Precordillera. Geological Survey of Canada Paper 90-9. In: Barnes, Ch, Williams, S.H. (Eds.), Advances in Ordovician Geology, pp. 245-258.

Schlagintweit, O., 1943. La posición estratigráfica del yacimiento de hierro de Zapla y la difusión del horizonte glacial de Zapla en la Argentina y en Bolivia. Rev. Minera, Geol. Miner. Buenos Aires 13, 115-127.

Schönian, F., 2003. Ambiente sedimentario de las diamictitas de la Formación Cancañiri en el área de Sella, sur de Bolivia. Rev. Técnica Yacimientos Pet. Fisc. Boliv. 21, 131-146.

Schönian, F., Egenhoff, S., 2007. A Late Ordovician ice sheet in South America: evidence from the Cancañiri tillites, southern Bolivia. Geol. Soc. Am. Special Pap. 423, 525-548.

Schönian, F., Egenhoff, S., Marcinek, J., Erdtmann, B., 1999. Glaciation at the
Ordovician-Silurian boundary in southern Bolivia. In: Kraft, P., Fatka, O. (Eds.), Quo vadis Ordovician, 43 (1-2). Acta Universitatis Carolinae, Geologica, pp. $175-178$.

Sempere, T., 1995. Phanerozoic evolution of Bolivia and adjacent regions. In: Tankard, A.J., Suárez Soruco, R., Welsink, H.J. (Eds.), Petroleum Basins of South America. American Association of Petroleum Geologists Memoir, 65, pp. 207-230.

Siccardi, A., Uriz, N.J., Rustán, J.J., Cingolani, C., 2014. Hirnantian?-Early silurian brachiopods from the sierra grande formation (North patagonian massif, río Negro province, Argentina). In: 4th. International Palaeontological Congress, Mendoza, Abstracts, p. 806.

Spalletti, L.A., Cingolani, C.A., Varela, R., 1991. Ambientes y procesos generadores de la sedimentitas portadoras de hierro en la plataforma silúrico-eodevónica de la Patagonia, República Argentina. Rev. del Mus. La Plata, sección Geol. 10, 305-318.

Suárez Soruco, R., 1995. Comentarios sobre la edad de la Formación Cancañiri. Rev. Técnica Yacimientos Pet. Fisc. Boliv. 16, 51-54.

Suárez Soruco, R., Benedetto, J.L., 1996. In: Primeros datos sobre la fauna de braquiópodos de la Formación San Benito en la Cordillera del Tunari, Cochabamba, Bolivia. Actas $12^{\circ}$ Congreso Geológico Boliviano, Tarija, 1, pp. 211-216.

Sutcliffe, O.E., Harper, D.A.T., Abdallah, A.S., Whittington, R.J., Craig, J., 2001. The development of an atypical Hirnantia brachiopod fauna and the onset of glaciations in the Late Ordovician of Gondwana. Trans. R. Soc. Edimburgh, Earth Environ. Sci. 92, 1-14.

Temple, J.T., 1965. Upper ordovician brachiopods from Poland and Britain. Acta Palaeontol. Pol. 10, 379-450.

Thomas, W.A., Astini, R.A., 2003. Ordovician accretion of the Argentine Precordillera terrane to Gondwana: a review. J. S. Am. Earth Sci. 16, 67-79.

Toro, B.A., 1995. Primer hallazgo de graptolitos del Silúrico (Llandoveriano) en la Cordillera Oriental, Provincia de Jujuy, Argentina. Ameghiniana 32, 375-384.

Toro, B.A., Halpern, K., Carrera, M., 2014. New records of Silurian graptolites from Cerro La Silla, San Juan province, precordillera Argentina. In: 4th. International Palaeontological Congress, Mendoza, Abstracts, 820.

Tortello, M.F., Clarkson, E.N.K., Uriz, N.J., Alfaro, M.B., Galeano Inchausti, J.C., 2008. Trilobites from the vargas peña formation (Llandovery) of Itauguá, eastern Paraguay. In: Rábano, I., Gonzalo, R., García Bellido, D. (Eds.), Advances in Trilobite Research. Cuadernos del Museo Geominero, 9, pp. 395-401.

Troedsson, G.T., 1918. Om skånes brachioposkiffre. Lunds Univ. Årsskrift 15 (3), $1-110$.

Uriz, N.J., Alfaro, M.B., Galeano Inchausti, J.C., 2008. Silurian (Llandovery) monograptids from the vargas peña formation (Paraná Basin, eastern Paraguay). Geol. Acta 6, 181-190.

Van Houten, F.B., 1985. Oolitic ironstones and contrasting Ordovician and Jurassic paleogeography. Geology 13, 722-724.

Van Houten, F.B., Bhattacharyya, D.P., 1982. Phanerozoic oolitic ironstones geologic record and Facies Model. Annu. Rev. Earth Planet. Sci. 10, 441-457.

Van Staden, A., Zimmermann, U., Chemale, F., Gutzmer, J., Germs, G.J.B., 2010. Correlation of Ordovician diamictites from Argentina and South Africa using detrital zircon dating. J. Geol. Soc. Lond. 167, 217-222.

Vandenbroucke, T.R.A., Gabbott, S.E., Paris, F., Aldridge, R.J., Theron, J.N., 2009 Chitinozoans and the age of the Soom Shale, an Ordovician black shale Lagerstätte, South Africa. J. Micropalaeontol. 28, 53-66.

Vavrdová, M., Isaacson, P.E., Díaz-Martínez, E., 2011. Early Silurian-Early Devonian acritarchs and prasinophytes from the Ananea and San Gabán Formations, southern Peru and their paleogeographic implications. Rev. Española Micropaleontol. 43, 157-172.

Vaz, P.T., da Mata Rezende, N., Wanderley Filho, J.R., Silva Travassos, A., 2007. Bacia do parnaiba. Bol. Gociencias Petrobras 15, 253-263.

Volkheimer, W., Pothe de Baldis, E.D., Baldis, B.A., 1980. Quitinozoos de la base del Silúrico de la Sierra de Villicum (provincia de San Juan, República Argentina). Rev. Mus. Argent. Ciencias Nat. 'Bernardino Rivadavia', Paleontol. 2, 125-135.

Waisfeld, B.C., Sánchez, T.M., 1993. Trilobites silúricos de la Formación Lipeón en el noroeste argentino (Sierra de Zapla, provincia de Jujuy). Ameghiniana 30, 77-90.

Wasifeld, B.G., Vaccari, N.E., 2003. Trilobites. In: Benedetto, J.L. (Ed.), Ordovician Fossils of Argentina. Secretaría de Ciencia y Tecnología, Universidad Nacional de Córdoba, pp. 295-409.

Young, T.P., 1989. Phanerozoic ironstones: an introduction and review. In: Young, T.P., Taylor, W.E.G. (Eds.), Phanerozoic Ironstones, 46. Geological Society Special Publications, pp. ix $-\mathrm{xxv}$.

Young, G.M., Minter, W.E.L., Theron, J.N., 2004. Geochemistry and palaeogeography of upper Ordovician glaciogenic sedimentary rocks in the Table Mountain Group, South Africa. Palaeogeogr. Palaeoclimatol. Palaeoecol. 214, 323-345.

Zhou, Z., Zhou, Z., Yuan, W., 2012. Late ordovician (Hirnantian) 'Mucronaspis (Songxites)'- dominant trilobite fauna from northwestern Zhejiang, China. Memoirs Assoc. Australas. Palaeontol. 42, 75-92. 